\title{
Employees' financial wellness, productivity, and firms' myopic behavior
}

\author{
Lars Helge Hass, Paul Hribar, Claudia Marangoni, and Roberto Pinto*
}

July 21, 2020

\begin{abstract}
We study how rank and file employees' financial wellness affects employers' myopic accounting decisions. By using staggered increases in consumer bankruptcy exemptions across US states to capture increments in employees' financial wellness, we find that firms reduce their real activities management, have fewer misstatements, and decrease their loss avoidance behaviors in response to higher consumer bankruptcy protection. We identify two channels that might explain these findings. First, we show that more consumer bankruptcy protection increases employees' productivity and reduces their absenteeism from the workplace, and second, we show that firm productivity and profitability improve when consumer bankruptcy protection increases. Thus, higher labor productivity and corporate profitability facilitate firms' achievement of their earnings-based targets, reducing the need for myopic performance-enhancing behaviors. Our evidence suggests that improving employees' financial wellness provides benefits to firms through higher profitability and fewer myopic decisions.
\end{abstract}

JEL classification: K35, J24.

Keywords: consumer bankruptcy, rank and file employees, myopic accounting decisions.

\footnotetext{
${ }^{*}$ Lars Helge Hass is at the Tippie College of Business, The University of Iowa, and Lancaster University Management School - Accounting and Finance Department, Paul Hribar is at the Tippie College of Business, The University of Iowa, Claudia Marangoni and Roberto Pinto are at Lancaster University Management School - Accounting and Finance Department. We thank Igor Goncharov and seminar participants at Lancaster University Management School for their comments and suggestions. All the errors are our own. E-mail addresses: 1.h.hass@lancaster.ac.uk (Lars Helge Hass), paul-hribar@uiowa.edu (Paul Hribar), c.marangoni@lancaster.ac.uk (Claudia Marangoni), and r.pinto@lancaster.ac.uk (Roberto Pinto).
} 


\section{Introduction}

Firms seek productive workers, and sponsor a variety of wellness programs to support a healthy and productive workforce (Oyer and Schaefer, 2005). ${ }^{1}$ Several factors affect workers' productivity, but financial wellness is one of the most relevant, in that finances represent a big source of stress for rank and file employees (hereafter also employees or workers). ${ }^{2}$ Concerns about the inability to pay off personal debt and uncertainty about the financial future undermine their financial wellness and increase their likelihood of suffering from physical and psychological health conditions (Richardson, Elliott, and Roberts, 2013). Despite anecdotal and survey evidence on the positive effects of better employees' financial wellness, there is limited empirical research on its impact on firms' performance and decision making. ${ }^{3}$

To contribute to the limited evidence, we investigate and find that systematic improvements in employees' financial wellness have positive spillover effects on firms. First, we show that better workers' financial wellness reduces their illness-related issues and absenteeism from the workplace. Second, we document that an increase in employees' financial wellness improves firms' productivity and profitability. Third, our results indicate that better workers' financial wellness leads to a decrease in firms' myopic accounting behaviors, in particular real activities management, misstatement, and loss avoidance. Taken together, the findings suggest that the benefits of better workers' financial wellness reduce managers' need to undertake myopic actions to meet their short-term earnings objectives at the expense of long-term economic value creation (Jensen (2005), Bhojraj, Hribar, Marc, and McInnis, 2009).

Identifying a relationship between firms' incentives to manage earnings and employees' financial wellness is challenging. The first hurdle is to find a good proxy for employees' financial wellness. The second is the endogenous matching between firms with heterogeneous manipulation incentives and employees with different degrees of financial wellness. We exploit the features of the US consumer bankruptcy laws to tackle these problems.

\footnotetext{
${ }^{1}$ Source: https://s2.q4cdn.com/997146844/files/doc_news/archive/88150356-0c7e-4f0c-9d5e-8a8aa45131b0.pdf

${ }^{2}$ CareerBuilder, in its 2017 survey, found that $78 \%$ of US workers are under financial pressure and live paycheck to paycheck. Source: https://www.forbes.com/sites/zackfriedman/2019/01/11/live-paycheck-topaycheck-government-shutdown. Moreover, a lack of financial wellness is associated with a combined cost of lost productivity and increased staff turnover at about 13-14\% of an employer's total payroll. Source: https://www.pwc.com/us/en/industries/private-company-services/pfs-employee-financial-education-practice.html

${ }^{3}$ Fidelity Research: www.fidelity.com/about-fidelity/institutional-investment-management/research-finds-the-toptwo-sources-of-stress-for-american-worker.
} 
Specifically, our empirical strategy exploits staggered increments in consumer bankruptcy exemptions across US states to identify improvements in individuals' financial wellness (Dobbie, Goldsmith-Pinkham, and Yang, 2017). Exemptions define the dollar value of debtors' assets that creditors cannot seize during personal bankruptcy proceedings. States that increase exemptions provide benefits to individuals with debt outstanding, allowing them to retain more of their assets when filing for bankruptcy. ${ }^{4}$ Moreover, higher exemptions might improve debtors' leverage in bargaining with creditors, who will have now a lower expected recovery rate on existing debt.

Another important feature of our framework is that more generous bankruptcy exemptions affect firms only through the impact on their employees' financial well-being. The bankruptcy code distinguishes between corporate and consumer bankruptcy. Provisions contained in the latter do not apply to corporate bankruptcy proceedings. This feature helps us argue in favor of complying with the exclusion restriction of our empirical model. In other words, our empirical specification can be seen as the second stage regression of a two-stage least square model where we use bankruptcy exemptions to instrument the unobservable changes in rank and file employees' financial wellness.

By comparing firms in states that increase exemptions to firms in states without such changes in a difference-in-differences framework, we show that higher exemptions lead to a reduction in the average number of injuries and illness-related cases with days away from work. Besides reducing workers' absenteeism, we document that increases in bankruptcy exemptions improve firms' productivity and profitability.

Using the same identification strategy, our evidence indicates that firms significantly reduce their myopic accounting behaviors when consumer bankruptcy exemptions increase. We study different types of myopic behaviors previously documented in the literature. First, we exploit archival residual measures constructed in a large panel dataset to examine real activities management and accrual-based earnings management. Second, we exploit restatement data to examine detected cases of financial misstatement. Third, we exploit discontinuities in the earnings distribution around the zero threshold to examine loss avoidance behaviors.

The evidence from our analysis shows that real activities management decreases in response to more generous bankruptcy exemptions. Economically, a 10\% increase in house-related (i.e., home-

\footnotetext{
${ }^{4}$ The economic magnitude of policies associated with consumer bankruptcy is substantial. Figure 1 shows the dollar value increase for each homestead exemption change in our dataset.
} 
stead) exemptions leads to a reduction in real activities management of 0.0018 (around $2.5 \%$ of corporate earnings). In contrast, we fail to find that firms adjust their discretionary accruals when the burden of employees' debt alleviates. Moreover, the evidence from actual misreporting cases and earnings discontinuities indicates that firms reduce financial misstatements and loss avoidance practices in response to better employees' financial wellness. Altogether, our results suggest that the positive effects of higher consumer bankruptcy protection on rank and file employees' financial wellness contribute to the trade-off between short- versus long-term firms' value-enhancing accounting decisions.

We further investigate cross-sectional differences in firms' real activities management in response to better rank and file employees' financial wellness. Specifically, we examine whether and how managerial incentives, labor intensity, and degree of unionization affect our evidence. We fail to find that real activities management decreases more when CEOs have stronger equity incentives, whereas we show that real activities management decreases more when firms are labor-intensive and highly unionized. Finally, we test the robustness of our results to alternative proxies for real activities management, and find evidence consistent with our main findings. Firms reduce real activities management when consumer bankruptcy exemptions increase.

This paper contributes to several streams of the literature. First, we contribute to the limited research on the role of employees on firms' myopic accounting decisions. Among the few studies, Dou, Khan, and Zou (2016) examine firms' response to enhanced unemployment benefits and find a reduction in abnormal accruals and an increased recognition of special items and writedowns for firms in states with more generous unemployment benefits. Our paper differs from theirs along two major dimensions. Firstly, we rely on policy shifts that affect firms only through their effects on employees. This is in sharp contrast with Dou et al. (2016) who use changes in unemployment benefits to capture variation in rank and file employees' perceptions of employment security. However, it is important to note that changes in unemployment benefits have a direct effect on firms because state unemployment insurance programs are funded using payroll taxes. Secondly, we focus on real activities management more than on accrual-based earnings management (as Dou et al. (2016) do) because we expect firms to take real actions when debt relief programs directly affect workers' absenteeism and productivity. In the same stream of literature, Gao, Zhang, and Zhang (2018) investigate and find that managers consider employees' turnover likelihood in 
their accounting choices, whereas Hass, Hribar, and Kalogirou (2019) identify labor mobility as a disciplining mechanism able to reduce firms' myopic accounting activities.

Second, and more broadly, our work relates to the studies on the effects of employer-employees relationships on firms' financial and real decisions. Among these studies, Pinto (2019) examines how bankruptcy exemptions affect corporate leverage and finds that firms issue more debt in response to policies that increase the protection of individuals' wealth in personal bankruptcy.

Third, our paper contributes to the literature analyzing individuals' precautionary response to income risk. Consistently, Low, Meghir, and Pistaferri (2010) show that changes in employeespecific risk (i.e., employee-specific uncertainty that exists independently of employers' characteristics) have substantial welfare implications, and call for more research on the consequences of changes in individuals' risk.

Finally, we add to the literature examining the positive effects of debt relief programs on individuals. Dobbie and Song (2015) show that Chapter 13 bankruptcy protection increases annual earnings by $\$ 5,562$, decreases five-year mortality by 1.2 basis points, and decreases five-year foreclosure rates by 19.1 basis points. Related to this, a complementary stream of literature documents the negative effects of indebtedness on individuals' physical and mental health conditions (e.g., Richardson et al., 2013).

The rest of the paper is organized as follows. Section 1 reviews prior literature on firms' myopic behavior and discusses the hypotheses development. Section 2 provides the institutional background on consumer bankruptcy laws in the United States and describes our empirical methodology. Section 3 describes the data and the main variables. Section 4 discusses the empirical findings, and Section 5 concludes.

\section{Prior literature and hypotheses development}

This section reviews the existing literature on firms' myopic behaviors and identifies rank and file employees as an understudied determinant. Based on this knowledge, we develop the hypothesis that better employees' financial wellness reduces firms' need and incentives to engage in myopic accounting activities. Unlike existing work studying implicit contracts and risk-sharing between employer and employees, our economic mechanism focuses on the tangible effects of rank and file 
employees' financial wellness on workplace absenteeism and productivity, and in turn its impact on firms' profitability and myopic accounting decisions.

\subsection{Related literature on firms' myopic accounting behavior}

Prior research has ascribed myopic behavior to the combination of strong distaste for losses and focus on short horizons (Thaler, Tversky, Kahneman, and Schwartz, 1997). In particular, firms engage in myopic behaviors by sacrificing long-term growth for the purpose of meeting short-term performance goals (Porter (1992), Bhojraj et al., 2009).

To meet short-term objectives at the expense of long-term value creation, firms can make financial reporting choices, such as changing accrual accounting methods or estimates, that obscure their true economic performance (Dechow, Ge, and Schrand, 2010). Specifically, managers exercise discretion and judgment regarding accounting choices (Cohen, Dey, and Lys, 2008). Alternatively, firms can engage in real activities management by altering the execution of real business transactions (Graham, Harvey, and Rajgopal (2005), Cohen and Zarowin, 2010). In other words, managers depart from normal business practices to mislead at least some stakeholders and make them believe that the reported financial performance has been achieved in the normal course of the operations (Roychowdhury, 2006).

Overall, through accrual-based earnings management firms shift earnings across periods to meet their short-term earnings targets (Cohen et al., 2008), whereas through real activities management firms forego positive net present value projects with long return horizons (Kothari, Mizik, and Roychowdhury, 2016). Importantly, both approaches sacrifice future earnings to boost current earnings. ${ }^{5}$

When firms' financial statements are not GAAP compliant and performance manipulations lead to fraudulent misconduct or other severe irregularities, regulators can force firms to restate their financial statements (Amiram, Bozanic, Cox, Dupont, Karpoff, and Sloan, 2018). Moreover, firms' incentives to avoid earnings decreases and losses and the desire of "consistent profitability", explain why myopic decisions are largely taken to cross the zero earnings "red line" (Hayn (1995), Burgstahler and Dichev, 1997).

\footnotetext{
${ }^{5}$ This assumes income-increasing earnings management. There are also reasons why firms might shift earnings to the future, but we are not concerned with those in this paper.
} 
Because myopic behaviors produce negative side effects for firms (e.g., Hribar and Jenkins (2004), McNichols and Stubben, 2008), the accounting literature has widely investigated which factors exacerbate or alleviate firms' engagement in such myopic behaviors (Dechow et al., 2010). Among the factors exacerbating firm accounting manipulations, there are firm operating characteristics, such as performance, leverage, growth and investment, and size (Dechow et al., 2010). For example, firms that are highly levered, hence closer to debt covenant violations, or that are

performing poorly, have more incentives to misreport their performance by managing earnings (e.g., Petroni (1992), Balsam, Haw, and Lilien, 1995).

In addition, there is considerable evidence that weak governance and monitoring mechanisms, such as internal controls, boards of directors, executive and non-executive committees, and shareholders, facilitate firms' undertaking of myopic accounting actions (e.g., Collins and DeAngelo (1990), Dechow and Sloan (1991), Abbott, Parker, and Peters, 2004). Relatedly, managerial incentives, especially those driven by compensation, increase the likelihood and the magnitude of accrual-based earnings management and real activities management (e.g., Efendi, Srivatsava, and Swanson, 2007). In contrast, several studies document that auditors reduce firms' myopic accounting decisions by exercising monitoring and scrutiny (e.g., Caramanis and Lennox, 2008).

Despite this sizable literature, there is limited evidence on the role of rank and file employees on firms' myopic accounting decisions to achieve short-term objectives. Among the few studies, Dou et al. (2016) show a decrease in firms' accrual-based earnings management and an increase in recognition of special items and write-downs in states with more generous unemployment benefits, whereas Gao et al. (2018) document that managers consider employees' turnover likelihood in their accounting choices. Finally, Hass et al. (2019) identify labor mobility as a disciplining mechanism able to reduce firms' engagement in myopic accounting decisions. By investigating how rank and file employees' financial wellness affects firms' incentives to engage in myopic accounting behaviors, our study adds to this limited evidence.

\subsection{Hypothesis development}

The Consumer Financial Protection Bureau (CFBT) defines financial wellness as "a condition wherein a person can fully meet current and ongoing financial obligations, can feel secure in their 
financial future, and is able to make choices that allow them to enjoy life". ${ }^{6}$ The improvement or deterioration of financial wellness impacts every aspect of individuals' lives, including their performance in the workplace.

Relatedly, existing research finds that the financial burden of personal debt is associated with a higher likelihood of suffering from physical and mental health conditions (Richardson et al., 2013). Moreover, survey results show that workers with financial problems are 5.8 times more likely not to finish their daily tasks on time, and 4.9 times more likely to experience diminished work quality. Combined, there is a total loss of $25-31$ workdays annually. ${ }^{7}$

Based on this evidence, we hypothesize that systematic improvements in rank and file employees' financial wellness produce positive spillover effects on firms. Specifically, we expect workers' absenteeism from the workplace for health-related problems to decrease, while workplace productivity to increase, as a result of better employees' financial wellness. Reduced absenteeism and enhanced productivity can be jointly seen as a reduction in the unit cost of labor borne by the firm, which, in turn, is likely to improve corporate profitability. Therefore, we formulate our first hypothesis as follows,

$H_{1}$ : Improvements in workers' financial wellness have positive spillover effects on their absenteeism from the workplace and on firms' productivity and profitability.

If workplace productivity and firms' profitability increase as a result of better rank and file employees' financial wellness (as predicted by $H_{1}$ ), firms can meet their earnings benchmarks while engaging less in myopic performance-enhancing activities. Specifically, we hypothesize that firms temporarily decrease myopic accounting behaviors when their workers' financial wellness improves.

We study firms' myopic behavior in response to enhanced workers' financial wellness along three dimensions. First, we examine real activities management and accrual-based earnings management. Second, we examine financial misstatements detected by regulators and sanctioned by subsequent restatements. Finally, we examine loss avoidance behaviors around the zero earnings threshold. This threefold strategy allows us to address our research question using different samples and alternative definitions of myopic behavior, thus mitigating the limitations of each proxy. Through real activities management and accrual-based earnings management, we exploit a panel dataset

\footnotetext{
${ }^{6}$ Source: https://www.consumerfinance.gov/practitioner-resources/financial-well-being-resources/.

${ }^{7}$ Employer's Guide to Financial Wellbeing 2018-19. Source: https://www.salaryfinance.com/us.
} 
to construct residual measures and provide large sample evidence, despite some methodological limitations identified by the literature (e.g., Chen, Hribar, and Melessa, 2018). Through restatement analysis, we focus on a small sample of detected cases of performance misreporting, whereas through loss avoidance tests, we examine the existence of discontinuities in the earnings distribution around a specific performance threshold.

Based on this strategy, we formulate three separate hypotheses - one for each myopic behavior - about firms' myopia as a response to better rank and file employees' financial wellness. The hypotheses are as follows,

$\mathrm{H}_{2}$ : Firms' real activities management and accrual-based earnings management decrease when workers' financial wellness increases.

$H_{3}$ : Firms' financial misstatements decrease when workers' financial wellness increases.

$H_{4}$ : Firms' loss avoidance practices decrease when workers' financial wellness increases.

\section{Institutional setting and empirical methodology}

In this section, we introduce the legal framework of the US consumer bankruptcy system whose unique features are exploited to capture improvements in employees' financial wellness. Moreover, we present the empirical strategy employed to quantify the effect of financial wellness on rank and file employees and firms.

\subsection{The US consumer bankruptcy framework}

The US consumer bankruptcy system features two filing procedures. The first is Chapter 7 bankruptcy filing. Under this procedure, debtors repay creditors by handing over all their unprotected assets to a bankruptcy trustee, which proceeds to their liquidation. Unsecured debt above the value of available assets is discharged, and hence filers do not use their future income to repay debt. The second is Chapter 13 bankruptcy filing. Under this procedure, debtors must propose a repayment plan to the judge who will decide on whether to accept or reject it. Moreover, Chapter 13 filers keep their assets but use their future income to repay the agreed-upon claims. 
In the case of Chapter 7 filing, creditors can only relinquish assets above the specific state exemption limits. There is a variety of assets exempted from liquidation. For simplicity, they can be categorized in homestead and non-homestead (or personal) exemptions. The former defines the equity value of debtors' principal residence that is protected in case of bankruptcy, whereas the latter defines the amount of any pre-specified asset that is exempted from bankruptcy. Common examples of assets categorized as non-homestead are motor vehicles, jewelry, tools of the trade including implements and books, and the wild card (special protection granting a specific dollar amount that can be applied to any personal item which is not listed).

In the case of Chapter 13 filing, filers do not give up their assets but propose a repayment plan. The amount chosen is not larger than what they would have lost under Chapter 7 filing (otherwise, it would be strictly preferable to default and file for Chapter 7). Hence, exemptions also affect the generosity of Chapter 13 bankruptcy procedure.

The consumer bankruptcy code underwent substantial changes in 2005 following the Bankruptcy Abuse Prevention and Consumer Protection Act (BAPCPA). The primary motivation for this Act was to make it more difficult for consumers to file for Chapter 7 bankruptcy. ${ }^{8}$ After this reform, Chapter 13 bankruptcy is considered as the base available option. Debtors who want to file for Chapter 7 need to pass a two-part means test. In the first part, a formula determines the filer's ability to pay $25 \%$ of his/her non-priority unsecured debt (e.g., credit card bills). In the second part, the debtor's income is compared to the median income of the state of residency. Filing for Chapter 7 bankruptcy is not an option for individuals with income above the state median and able to afford $25 \%$ of the non-priority unsecured debt. Conditional on the court's approval, Chapter 7 can be an option only if the filer's income lies below the state median even if he/she can afford $25 \%$ of the unsecured debt.

Evidence on filings confirms that debtors perceived this reform as weakening their positions. As shown in Figure 2, people with a positive option value of filing for bankruptcy took advantage of Chapter 7 before the provisions in the BAPCPA became effective. In 2005, there were over

\footnotetext{
${ }^{8}$ In the Opening Statement at the Bankruptcy Reform Hearing (Senate Committee on the Judiciary), Sen. Chuck Grassley said "this legislation eliminates some of the opportunities for abuse that exist under the current system. Our current system allows wealthy people to continue to abuse the system at the expense of everyone else. People with good incomes can run up massive debts and then use bankruptcy to get out of honoring them. Omissis... it has been estimated that every American family pays as much as $\$ 550$ a year in a hidden tax as a result of the actions from these abuses. My bankruptcy reform legislation will help eliminate this hidden tax by implementing a means test to make wealthy people who can repay their debts actually honor them".
} 
2 million Chapter 7 bankruptcy filings. This strong reaction also suggests that individuals are receptive to changes in consumer bankruptcy generosity and value the protection provided by debt relief programs.

Overall, bankruptcy exemptions provide natural leverage (i.e., more bargaining power) to help debtors renegotiate claims with creditors, allowing informal debt relief even when there is not a formal bankruptcy filing. Although consumer bankruptcy is regulated at the federal level, states can set their own exemption levels. Filers are subject to the exemptions of the state in which they reside. Our empirical strategy exploits the large variation in the generosity of the bankruptcy exemptions across states. The variation is particularly large for the homestead exemptions, which is the largest and most important exemption category. We use increases in exemptions to capture gains in rank and file employees' financial wellness.

\subsection{Empirical methodology}

Our empirical model exploits staggered changes in consumer bankruptcy exemptions across US states and over time to account for variation in employees' financial wellness in a difference-indifferences framework. The empirical analysis consists of two parts. First, we study whether and how bankruptcy exemptions affect rank and file employees. In particular, we examine how more generous debt relief programs reduce workers' absenteeism because of injuries and illness-related problems, and improve workplace productivity and firm profitability. Second, we study the effects of higher bankruptcy exemptions on firms' myopic accounting decisions. In general, we compare outcome variables in states that increase exemptions to outcome variables in states without such changes.

To estimate the effect of higher bankruptcy exemptions on rank and file employees' absenteeism from the workplace, we exploit establishment-level injury data from the Bureau of Labor Statistics' (BLS) annual Survey of Occupational Injuries and Illnesses (SOII). Because the firm's plants can be located in different states from the firm's headquarter, and can be therefore subject to different bankruptcy regimes, establishment-level data allow us to measure more accurately the bankruptcy regime workers are subject to. 
Our baseline establishment-level linear model is as follows,

$$
y_{\text {est }}=\alpha+\beta_{1} \log \text { Homestead }_{\text {st }-1}+\beta_{2} \text { Log Non-Homestead } d_{s t-1}+\delta \boldsymbol{Z}_{\text {st-1 }}+a_{t}+b_{s}+\epsilon_{\text {est }}
$$

where the dependent variable, $y$, is one of our two injury- and illness-related measures of absenteeism for rank and file employees working in establishment $e$ located in state $s$, and during year $t$. Log Homestead and Log Non-Homestead are the natural logarithms of state-level homestead and non-homestead consumer bankruptcy exemption increases, respectively. The model includes timevarying state controls $(\boldsymbol{Z})$ to account for heterogeneity in local macroeconomic and labor conditions. In addition, the model includes time fixed-effect, $a_{t}$, to account for unobservable time-shocks, and state fixed-effects, $b_{s}$, to account for time-invariant state unobservable characteristics.

Similarly, we estimate the following firm-level linear model,

$$
y_{i j s t}=\alpha+\beta_{1} \log \text { Homestead }_{s t-1}+\beta_{2} \text { Log Non-Homestead } \text { Ht }-1_{1}+\delta \boldsymbol{Z}_{s t-1}+\gamma \boldsymbol{X}_{i j s t-1}+a_{t}+b_{i}+\epsilon_{i j s t}
$$

where in this case our dependent variable is measured at firm-level and can be a productivity, profitability, or accounting myopia proxy for firm $i$ belonging to industry $j$, and headquartered in state $s$ in year $t$. In this specification, besides state-level variables, $\boldsymbol{Z}$, we add time-varying firm controls, $\boldsymbol{X}$, to account for observable firm-specific characteristics. Moreover, we include year fixed effects, $a_{t}$, to remove unobservable time-shocks, and firm fixed-effects, $b_{i}$, to control for timeinvariant firm characteristics. Firm fixed-effects ensure that estimates reflect actual changes in the outcome variables and exemptions generosity over time, and not simple cross-sectional correlations. The detailed description of all variables is provided in Appendix A.

We compute robust state-level clustered standard errors to account for the within-group correlation structure. Bertrand, Duflo, and Mullainathan (2004) show that, in such a setting, if the number of groups is sufficiently large (they provide a rule of thumb of 50 groups), clustering partially mitigates the problem imposed by repeated cross-sectional and serially correlated outcome variables. Our estimations on the full sample include 51 groups (i.e., 50 states and District of Columbia) for clustered standard errors.

The empirical identification reported in equation 2 comes from within states across time varia- 
tion of bankruptcy exemptions. This identification strategy relies on the assumption that shifts in consumer bankruptcy exemptions are quasi-random with respect to firms' myopic decisions. Endogeneity concerns are alleviated by the fact that consumer bankruptcy policies affect firms only through their effects on rank and file employees' financial wellness. However, there could still be time-varying unobservable variables correlating with both firms' myopic accounting decisions and shifts in bankruptcy exemptions. To assess this possibility, we look at parallel trends. In the absence of treatment, the average response of firms in both treated and control groups should be the same. We use pre-treatment data to show that trends in one of our main measures of myopic behavior (i.e., real activities management), follow a similar path in both groups of firms. Specifically, Figure 3 indicates an absence of systematic differences between treated and control firms before the increases in consumer bankruptcy exemptions.

\section{Data and variables description}

We construct our dataset using several sources. First, we hand-collect state-level data on consumer bankruptcy exemptions - homestead and non-homestead - as defined in Chapter 7 of the US Bankruptcy Code, from state legal documents for all US states from 1995 to 2008. Our dataset includes 36 homestead and 73 non-homestead exemption increases for the sample period 1995-2005. ${ }^{9}$ The sample ends in 2005 because the enactment of the Bankruptcy Abuse Prevention and Consumer Protection Act (BAPCPA) that occurred in 2005 made it more complex and less relevant to file for bankruptcy. ${ }^{10}$

Second, we collect financial data to construct firm-specific control variables from Compustat. Firm controls are as follows. Big 4 is an indicator equal one if firm $i$ is audited by a Big 4 audit firm, and zero otherwise; Book Leverage is the ratio between short- and long-term debt and lagged total assets; Dividend is the ratio between dividends and lagged total assets; Market-to-Book is the ratio between the market value of assets and the book value of assets; $R O A$ is the ratio between

\footnotetext{
${ }^{9}$ We focus on increases in exemptions because of the limited number of reductions. In our sample, there is only 1 case of homestead and 14 cases of non-homestead exemption decreases, respectively. The disproportion in the number of events reflects the fact that non-homestead exemptions are defined as the sum of exempted values of several personal assets. Even if the value of non-homestead exemptions changes just for one asset, this counts as a shock to non-homestead exemptions.

${ }^{10}$ The BAPCPA is a legislative act that significantly changed the United States Bankruptcy Code. This federal bill made it far more difficult for some consumers to file for bankruptcy under Chapter 7 (where most of the debt gets discharged) and hence exemptions less relevant.
} 
operating income before depreciation and lagged total assets; Size is the natural logarithm of total assets; and Total Accruals is the ratio between total accruals and lagged total assets.

Third, we obtain macroeconomic and labor data to construct state-specific control variables for every state from 1995 to 2005. Specifically, data on GDP growth rate (variable GDP Growth), disposable income (variable Per-capita Income), and unemployment rate (variable Unemployment Rate) are from the US Bureau of Economic Analysis (BEA); data about state-level union coverage are from the Barry Hirsch and David Macpherson website, ${ }^{11}$ whereas unemployment insurance data (variable UI) are from the US Department of Labor website - "Significant Provisions of State Unemployment Insurance Laws" - available from $1977 .{ }^{12}$

Moreover, and consistent with Cohn and Wardlaw (2016), we collect data from the Bureau of Labor Statistics' website and Compustat to construct our proxies for workers' absenteeism, labor and firm productivity, and corporate profitability. Specifically, using data from the Bureau of Labor Statistics' (BLS) annual Survey of Occupational Injuries and Illnesses (SOII), we alternatively measure rank and file employees' absenteeism from the workplace as the incidence rate of total injuries and illness cases (variable $T C R$ ), and the incidence rate of injuries and illness cases leading to days away from work (variable $D A F W I I$ ). Using Compustat data, we measure labor productivity as sales per employee (variable Sales per Employee), and total firm productivity (variable Total Productivity) as per İmrohoroğlu and Tüzel (2014). Firm profitability is alternatively measured as earnings before interest and taxes scaled by lagged total assets (Total Earnings), total accruals scaled by lagged total assets (Total Accruals), and cash flow from operations scaled by lagged total assets (Cash Flow).

Finally, we collect data from Compustat and Audit Analytics to construct our proxies for myopic accounting decisions. To measure real activities management and accrual-based earnings management, we apply the commonly used two-step procedure consisting of using the residuals from ordinary least squares as dependent variable in a second regression (Dechow et al., 2010). Because we are aware that this procedure could lead to biased estimates and standard errors, hence incorrect inferences, we later supplement these measures with alternative proxies for myopic accounting decisions (Chen et al., 2018).

\footnotetext{
${ }^{11}$ Source: http://www.unionstats.com.

${ }^{12}$ Source: https://workforcesecurity.doleta.gov/unemploy/statelaws.asp
} 
We follow Roychowdhury (2006) to measure real activities management, (i.e., $R A M)$. Specifically, $R A M$ is the combination of three proxies, i.e., abnormal discretionary expenses, abnormal cash flow from operations, and abnormal production costs. These measures capture the reduction in discretionary expenses, such as advertising, $R \& D$, and SG\&A expenses, the acceleration of the timing of sales through increased price discounts or more lenient credit terms, and the reporting of a lower cost of goods sold through increased production.

To construct such real activities management proxy, we start by estimating the following models for each year-industry (2-digit SIC) group:

$$
\begin{aligned}
& \frac{\text { Disx }_{i t}}{\text { Assets }_{i t-1}}=\kappa_{1 t} \frac{1}{\text { Assets }_{i t-1}}+\kappa_{2 t} \frac{\text { Sales }_{i t-1}}{\text { Assets }_{i t-1}}+\epsilon_{i t} \\
& \frac{\text { CFO }_{i t}}{\text { Assets }_{i t-1}}=\kappa_{1 t} \frac{1}{\text { Assets }_{i t-1}}+\kappa_{2 t} \frac{\text { Sales }_{i t}}{\text { Assets }_{i t-1}}+\kappa_{3 t} \frac{\Delta \text { Sales }_{i t}}{\text { Assets }_{i t-1}}+\epsilon_{i t} \\
& \frac{\text { Prod }_{i t}}{\text { Assets }_{i t-1}}=\kappa_{1 t} \frac{1}{\text { Assets }_{i t-1}}+\kappa_{2 t} \frac{\text { Sales }_{i t}}{\text { Assets }_{i t-1}}+\kappa_{3 t} \frac{\Delta \text { Sales }_{i t}}{\text { Assets }_{i t-1}}+\kappa_{4 t} \frac{\Delta \text { Sales }_{i t-1}}{\text { Assets }_{i t-1}}+\epsilon_{i t}
\end{aligned}
$$

where $D i s x_{i t}$ represents discretionary expenditures defined as the sum of advertising, $\mathrm{R} \& \mathrm{D}$, and SG\&A expenses for firm $i$ in year $t, C F O_{i t}$ represents cash flow from operations for firm $i$ in year $t$, and Prod $_{i t}$ represents production costs defined as the sum of costs of goods sold and the change in inventories for firm $i$ in year $t$. Sales $i t$ measures total sales for firm $i$ in year $t, S_{\text {Sales }} i t$ measures total sales for firm $i$ in year $t-1$, and $\Delta$ indicates the annual change in Sales (from $t-1$ to $t$ or from $t$-2 to $t$-1). Finally, Assets it $-1_{1}$ represents total assets for firm $i$ in year $t$-1. We measure abnormal discretionary expenses, abnormal cash flow form operations, and abnormal production costs as the difference between the actual values and the values predicted from equations (3), (4), and (5), respectively.

Our main measure of real activities management, $R A M$, is the combination of abnormal discretionary expenses, abnormal cash flow from operations, and abnormal production costs. Specifically, in the spirit of Cohen and Zarowin (2010), we compute this metric (i.e., $R A M$ ) as the sum of abnormal discretionary expenses, abnormal cash flow from operations (both multiplied by negative one), and abnormal production costs (Abnormal Disx., Abnormal CFO, and Abnormal Prod., respec- 
tively). Multiplying by negative ones ensures that higher (lower) values correspond to more (less) real activities management for all metrics. Because the proxies for real activities management are residuals to be used as dependent variables, in robustness (untabulated) tests we remove the bias identified in Chen et al. (2018) by including all first stage regressors in our second stage regressions.

We further measure accrual-based earnings management in two ways following Dechow, Sloan, and Sweeney (1995) and Dechow and Dichev (2002), respectively. To construct the first proxy, we start by estimating the following model for each year-industry (2-digit SIC) group:

$$
\frac{\text { Total Acruals }_{i t}}{\text { Assets }_{i t-1}}=\kappa_{1 t} \frac{1}{\text { Assets }_{i t-1}}+\kappa_{2 t} \frac{\Delta \text { Sales }_{i t}-\Delta \text { Rec }_{i t}}{\text { Assets }_{i t-1}}+\kappa_{3 t} \frac{P P E_{i t}}{\text { Assets }_{i t-1}}+\epsilon_{i t}
$$

where Total Accruals $i$ represents total accruals for firm $i$ in year $t$ measured as per Hribar and Collins (2002), $\Delta$ Salesit $_{i t}$ measures the annual change in total sales for firm $i$ in year $t, \Delta R e c_{i t}$ measures the annual change in accounts receivables for firm $i$ in year $t, P P E_{i t}$ measures gross property, plant, and equipment for firm $i$ in year $t$, and Assets $_{i t-1}$ represents total assets for firm $i$ in year $t$-1. We measure discretionary accruals (variable Discretionary Accruals Modified-Jones) as the difference between the actual values and the values predicted from equation (6).

To construct the second proxy for accrual-based earnings management, we start by estimating the following model for each year-industry (2-digit SIC) group:

$\frac{\text { Total Acruals }_{i t}}{\text { Assets }_{i t-1}}=\kappa_{1 t} \frac{C F O}{\text { Assets }_{i t}}+\kappa_{2 t} \frac{C F O_{i t-1}}{\text { Assets }_{i t-1}}+\kappa_{3 t} \frac{\text { CFO }_{i t+1}}{\text { Assets }_{i t+1}}+\kappa_{4 t} \frac{\Delta \text { Sales }_{i t}}{\text { Assets }_{i t-1}}+\kappa_{5 t} \frac{P P E_{i t}}{\text { Assets } s_{i t-1}}+\epsilon_{i t}$

where Total Accruals $i$ represents total accruals for firm $i$ in year $t$ measured as per Hribar and Collins (2002), CFO represents cash flow from operations for firm $i$ in years $t, t-1$, or $t+1, \Delta$ Sales $_{i t}$ measures the annual change in total sales for firm $i$ in year $t, P P E_{i t}$ measures gross property, plant, and equipment for firm $i$ in year $t$, and Assets represents total assets for firm $i$ in years $t, t-1$, or $t+1$. We measure discretionary accruals (variable Discretionary Accruals Dechow-Dichev) as the difference between the actual values and the values predicted from equation (7).

To test whether firms have fewer misstatements when consumer bankruptcy exemptions increase, we construct a sample of firms that have misstated their financial statements at least once during the sample period 1995-2005. We collect misstatement information from the Non-Reliance 
Restatement database of Audit Analytics, which allows to detect not only the date of restatements, but more importantly, the fiscal year(s) when firms have misstated their accounting numbers. Furthermore, detected cases of financial misstatement provide an ex-post measure of severe accrualbased earnings manipulations, thus allowing us to overcome some of the limitations associated with discretionary accruals measures (Chen et al., 2018).

Using restatement data, we construct the following variables: Restatement, an indicator equal 1 if firms have misstated their financial statements in fiscal year $t$ and are sanctioned by an ex-post restatement, and 0 otherwise; Restatement $U p$, an indicator equal 1 if firms have misstated their financial statements upward in fiscal year $t$ and are sanctioned by an ex-post restatement, and 0 otherwise; Num. Restatement, the number of misstatements that firms have engaged in during fiscal year $t$; and Num. Restatement $U p$, the number of upward misstatements that firms have engaged in during fiscal year $t$.

Finally, to test loss avoidance firms' myopic behavior, we examine whether the distribution of changes in earnings (measured as change in net income scaled by lagged total assets) before visà-vis after bankruptcy exemptions increase are discontinuous at zero and abnormally high above such threshold. Relatedly, we perform manipulation tests based on the local-polynomial density discontinuity at the zero earnings threshold.

\section{Empirical findings}

In this section, we present the empirical results. First, we discuss the evidence on the effects of increases in bankruptcy exemptions on rank and file employees' absenteeism from the workplace and on firms' productivity and profitability. Second, we describe the consequences of better rank and file employees' financial wellness on firms' myopic accounting decisions. Finally, we present results of cross-sectional and robustness tests to reinforce our baseline findings.

\subsection{Impact of bankruptcy exemptions on employees and firms' productivity and profitability}

In the first part of our empirical tests, we analyze the impact of bankruptcy exemptions on rank and file employees' absenteeism from the workplace due to injuries and illness, and on firms' productivity and profitability (hypothesis $\mathrm{H}_{1}$ ). In Table 2, we show that more generous exemptions decrease rank and file employees' absenteeism, and increase labor and firm productivity. The first 
two columns ot Table 2 present results of the establishment-level analysis on employees' absenteeism. The dependent variables are $T C R$ in column (1), and DAFWII in column (2), respectively. TCR measures the incidence rate of total injuries and illness cases, whereas DAFWII measures the incidence rate of injuries and illness cases leading to days away from work. In column (2) of Table 2, we find that a $10 \%$ increase in homestead exemptions lead to a $2.2 \%$ decrease in injuries and illness cases with days away from work.

In columns (3) and (4) of the same table, we show that increased bankruptcy exemptions improve labor and firm productivity. We measure labor and firm productivity as Sales per Employee in column (3) and Total Productivity (computed following İmrohoroğlu and Tüzel, 2014) in column (4). The estimates on both measures of productivity display a similar magnitude: higher bankruptcy exemptions lead to an increase in productivity. Specifically, a $10 \%$ increase in homestead exemptions leads to an increase in sales per employee of 14 basis points, and an increase in total firm productivity of 16 basis points. Overall, the evidence in Table 2 suggests that policies that improve the financial wellness of rank and file employees have positive spillover effects on labor supply and firm productivity.

In Table 3, we analyze the effects of increased bankruptcy exemptions on firms' performance and find a positive and statistically significant relationship. In column (1), the dependent variable is earnings before interest and taxes scaled by lagged total assets (Total Earnings). Column (2) dependent variable is total accruals scaled by lagged total assets (Total Accruals), whereas column (3) dependent variable is cash flow from operations scaled by lagged total assets (Cash Flow). By construction, the sum of Total Accruals and Cash Flow equals Total Earnings. The evidence in Table 3 shows that when rank and file employees' financial wellness improves through bankruptcy exemptions increases, firms' profitability improves. Specifically, total profitability and its cash component (Total Earnings and Cash Flow, respectively) increase. These results support the evidence in Table 2, highlighting positive spillover effects of better rank and file employees' financial wellness.

\subsection{Impact of bankruptcy exemptions on firms' myopia}

In the second part of our empirical tests, we use three empirical strategies to investigate whether firms make fewer myopic accounting choices in response to increases in consumer bankruptcy exemp- 
tions (hypotheses $\mathrm{H}_{2}, \mathrm{H}_{3}$, and $\mathrm{H}_{4}$ ). Overall, our empirical analysis supports the idea that positive effects of policies improving rank and file employees' financial wellness lead to firms undertaking fewer myopic accounting actions.

First, we analyze firms' myopic decisions by looking at real activities management and accrualbased earnings management. Table 4 reports results from estimating the model in Equation (2) when the dependent variable measures real activities management $(R A M)$. We find that more generous consumer bankruptcy protection leads to a decrease in firms' real activities management. Column (1) of Table 4 shows the coefficient estimates of the test independent variables (Log Homestead and Log Non-Homestead) without any control variable, whereas column (2) summarizes the results of our baseline specification, where we control for time-varying firm characteristics, state macroeconomic factors, time-invariant firm unobservable characteristics, and time-varying unobservables. The estimated effects are both statistically and economically meaningful. Specifically, we find that a $10 \%$ increase in homestead exemptions (around $\$ 6,070$ ) leads to a real activities management reduction of 0.0018 , which is around $2.5 \%$ of earnings, based on a ROA mean for treated firms of around 7.5\%. Such increment in exemptions represents a sizeable fraction (around $23 \%$ ) of the individuals' average disposable income. ${ }^{13}$

In contrast, we find that non-homestead exemptions do not affect corporate real activities management. The estimates across specifications are neither statistically nor economically significant. This result is consistent with non-homestead exemptions being smaller in dollar value than homestead exemptions ( $\$ 7,661$ versus $\$ 60,704$, on average), hence affecting a limited portion of individuals' wealth.

Firms are assigned to a state based on their headquarters' location. Workers of firms' plants located in states different from the headquarter, are subject to the bankruptcy laws of their state of

\footnotetext{
${ }^{13}$ Based on $\mathrm{H}_{1}$, we test and find that rank and file employees are less absent from the workplace and become more productive after bankruptcy exemptions increase, thus being more likely to positively contribute to firms' cash flows and production. Although the empirical model we use to estimate our main proxy for real activities management, $R A M$, includes abnormal cash flows and abnormal production, it does not control for workers' normal contribution to cash flows and productivity. Therefore, abnormal cash flows could be mechanically higher because of workers' enhanced performance, rather than because of firms' myopic decisions. Similarly, when workers become more productive, firms' production is likely to increase. The residuals from equation 5 - the real activities management proxy capturing abnormal productivity and measured by cost of goods sold plus changes in inventory - could be mechanically higher than in the absence of the shock to employees' financial wellness. However, both mis-measurements should work against us finding evidence of reduced myopia. Moreover, our results are robust across alternative real activities management proxies that do not include abnormal cash flows and abnormal production. More details on these robustness tests are reported in Table 8.
} 
location. Therefore, if the workforce is geographically dispersed, we might be capturing the benefits of bankruptcy exemptions with error. To address this concern, we split the sample between firms in industries with less and more dispersed workforce (as in Agrawal and Matsa, 2013). Columns (3) and (4) of Table 4 report the results of this subsample analysis. We find that increases in bankruptcy exemptions lead to a decrease in firms' myopic real activities management when the workforce is less disperse, hence when rank and file employees are more likely to work in the same state as that of the headquarter.

In Table 5, we investigate whether firms adjust their discretionary accruals in response to more generous consumer bankruptcy exemptions, but we fail to find evidence in support of this prediction. Specifically, in both columns (1) and (2) of Table 5, results show that homestead and non-homestead exemptions do not affect accrual-based earnings management, measured by the modified Jones' model (Dechow et al., 1995) and the Dechow and Dichev's model (Dechow and Dichev, 2002). Altogether, the evidence provided by our panel dataset suggests that accrual-based earnings management and real earnings management act as substitutes.

Second, we focus on firms that misstate their financial statements during our sample period. Detected cases of misstatement leading to subsequent restatements provide an ex-post measure of accrual-based earnings manipulations that are not GAAP compliant, thus allowing us to overcome some of the limitations associated with discretionary accruals measures (Chen et al., 2018). In Table 6, we provide evidence that firms reduce financial misstatements after bankruptcy exemptions increase. The likelihood and the number of misstatements revealed by ex-post restatements decrease when rank and file employees' financial wellness improves.

Finally, we examine loss avoidance firms' behavior around the zero earnings threshold. Because profitability improves in response to enhanced employees' financial wellness (see Table 3), we expect firms to have less need to manage their earnings to obtain positive results and maintain "consistent profitability" (Hayn, 1995). To test firms' loss avoidance behaviors, we examine whether the distributions of changes in earnings before vis-à-vis after bankruptcy exemptions increases are discontinuous at zero and abnormally high above such threshold. Consistent with less need to engage in loss avoidance practices when firms' performance increases, Figure 4 shows that during the three years before exemptions increase, earnings changes around zero are discontinuous, whereas during the three years following bankruptcy exemptions increases, the discontinuity 
at zero is less pronounced. Relatedly, the histograms reported at the top of Figure 4 highlight a shift to the positive region in the distribution of changes in earnings after bankruptcy exemptions increase compared to before such changes. Overall, consistent with the evidence in Tables 4 and 6, results suggest that better performing firms have less need to manage their performance to meet short-term earnings-based targets.

\subsection{Cross-sectional and robustness tests}

Restatements are likely to capture detected cases of severe accrual-based earnings manipulations, thus addressing some concerns that our discretionary accruals proxies are biased (Chen et al. (2018), Amiram et al., 2018). Similarly, loss avoidance tests provide indirect evidence that either real activities management or accrual-based earnings management has occurred. In contrast, our real activities management proxies do not have ex-post measures of detected cases. Therefore, to alleviate concerns that coefficients and standard errors are biased, we investigate cross-sectional differences in firms' real activities management in response to better rank and file employees' financial wellness. Table 7 presents the results of our cross-sectional tests, where we analyze the effect of homestead exemptions on firms with different degrees of managerial equity incentives, labor intensity, and state unionization. In columns (1) and (2) of Table 7, we fail to find that firms decrease real activities management in response to greater consumer bankruptcy protection when CEOs have stronger equity incentives. Managerial incentives are proxied by CEO pay-performance sensitivity (i.e., delta) measured as per Coles, Daniel, and Naveen (2006).

In contrast, in columns (3) and (4) of Table 7, we provide evidence that labor intensive firms reduce their real activities management in response to higher consumer bankruptcy exemptions more than non-labor intensive firms (firms' labor intensity is measured as per Donangelo, Gourio, Kehrig, and Palacios, 2019). This coheres with the idea that shocks to the workforce are more relevant for firms with higher labor-to-capital ratios. Finally, as reported in columns (5) and (6) of Table 7, we show that higher employees' bargaining power, captured by a stronger degree of unionization, affects more employers' real activities management reduction.

Taken together, the results of our cross-sectional tests suggest that improvements in employees'

financial wellness induced by more generous consumer bankruptcy protection generate positive externalities on employers, who engage less in real activities management. This effect is stronger 
for firms whose labor input is more important and where workers' bargaining power over the management is stronger.

In Table 8, we examine the robustness of our findings to alternative proxies for real activities management and find consistent results. Specifically, column (1) dependent variable is abnormal discretionary expenses measured as per Equation (3) and multiplied by negative one (Abnormal Disx.). Column (2) dependent variable is abnormal discretionary cash flow from operations measured as per Equation (4) and multiplied by negative one (Abnormal CFO), whereas column (3) dependent variable is abnormal production costs measured as per Equation (5) (Abnormal Prod.). Column (4) dependent variable is the sum of abnormal discretionary expenses (multiplied by negative one) and abnormal production costs, whereas column (5) dependent variable is the sum of abnormal discretionary expenses and abnormal cash flow from operations (both multiplied by negative one). Results are robust across all specifications and confirm our main findings that real activities management decreases when consumer bankruptcy exemptions increase.

Finally, we investigate whether unemployment insurance and per-capita disposable income have a mediating effect on the relation between enhanced consumer bankruptcy protection and real activities management. The results of this analysis, reported in Table 9, show that unemployment insurance and individuals' wealth do not affect the relationship between consumer bankruptcy exemptions and firms' real activities management.

We construct three indicator variables capturing the generosity of state unemployment insurance (i.e., small, medium, and large $U I$ ) and interact each indicator with our main test variable, Log Homestead, which measures the magnitude of homestead exemptions increases. Results reported in Column (2) of Table 9 do not highlight differences in the relationship between homestead exemptions and firms' real activities management across different levels of unemployment insurance. This evidence suggests that subsidies to unemployment do not substitute consumer bankruptcy social programs. Similarly, we construct three indicator variables for states with small, medium, and large per-capita disposable income (Per-capita Income) and interact them with our Log Homestead exemption test variable. Results reported in Column (3) of Table 9 indicate that consumer bankruptcy protection affects real activities management regardless of individuals' wealth levels. 


\section{Conclusion}

In this paper, we investigate whether the consumer bankruptcy protection programs that alleviate the burden of personal debt and improve rank and file employees' financial wellness affect firms' myopic behavior. By exploiting staggered increments in consumer bankruptcy generosity across US states from 1995 to 2005, we show that firms reduce their real activities management, have fewer misstatements, and exhibit less loss avoidance behavior in response to higher consumer bankruptcy protection. We document two results that help explain these findings. First, we show that more consumer bankruptcy protection increases employees' productivity and reduces their absenteeism from the workplace, and second, we show that firm productivity and profitability im-

prove when consumer bankruptcy protection increases. Furthermore, results are stronger for more labor-intensive firms and for firms in states highly unionized. Taken together, our results indicate that rank and file employees' financial wellness affects their performance at work and produces positive externalities on firms' decisions to undertake fewer myopic accounting actions. 


\section{References}

Abbott, Lawrence J., Susan Parker, and Gary F. Peters, 2004, Audit Committee Characteristics and Restatements, Auditing: A Journal of Practice and Theory 23, 69-87.

Agrawal, Ashwini K., and David A. Matsa, 2013, Labor Unemployment Risk and Corporate Financing Decisions, Journal of Financial Economics 108, 449-470.

Amiram, Dan, Zahn Bozanic, James D. Cox, Quenting Dupont, Jonathan M. Karpoff, and Richard Sloan, 2018, Financial reporting fraud and other forms of misconduct: a multidisciplinary review of the literature, Review of Accounting Studies 23, 732-783.

Balsam, Steven, In-Mu Haw, and Steven B. Lilien, 1995, Mandated accounting changes and managerial discretion, Journal of Accounting and Economics 20, 3-29.

Bertrand, Marianne, Esther Duflo, and Sendhil Mullainathan, 2004, How Much Should we Trust Differences-in-Differences Estimates?, The Quarterly Journal of Economics 119, 249-275.

Bhojraj, Sanjeev, Paul Hribar, Picconi Marc, and John McInnis, 2009, Making Sense of Cents: An Examination of Firms That Marginally Miss or Beat Analyst Forecasts, Journal of Finance 64, $2361-2388$.

Burgstahler, David, and Ilia Dichev, 1997, Earnings management to avoid earnings decreases and losses, Journal of Accounting and Economics 24, 99-126.

Caramanis, Constantinos, and Clive Lennox, 2008, Audit effort and earnings management, Journal of Accounting and Economics 45, 116-138.

Chen, Wei, Paul Hribar, and Samuel Melessa, 2018, Incorrect Inferences When Using Residuals as Dependent Variables, Journal of Accounting Research 3, 751-796.

Cohen, Daniel A., Aiyesha Dey, and Thomas Z. Lys, 2008, Real and Accrual-Based Earnings Management in the Pre- and Post-Sarbanes-Oxley Periods, The Accounting Review 83, 757-787.

Cohen, Daniel A., and Paul Zarowin, 2010, Accrual-based and real earnings management activities around seasoned equity offerings, Journal of Accounting and Economics 1, 2-19. 
Cohn, Jonathan B., and Malcom I. Wardlaw, 2016, Financing Constraints and Workplace Safety, The Journal of Finance 71, 2017-2058.

Coles, Jeffrey L., Naveen D. Daniel, and Lalitha Naveen, 2006, Managerial incentives and risktaking, Journal of Financial Economics 79, 431-468.

Collins, Daniel W., and Linda DeAngelo, 1990, Accounting information and corporate governance: Market and analyst reactions to earnings of firms engaged in proxy contests, Journal of Accounting and Economics 13, 213-247.

Dechow, Patricia M., and Ilia D. Dichev, 2002, The quality of accruals and earnings: The role of accrual estimation errors, The Accounting Review Supplement, 35-59.

Dechow, Patricia M., Weili Ge, and Catherine Schrand, 2010, Understanding earnings quality: A review of the proxies, their determinants and their consequences, Journal of Accounting and Economics 50, 344-401.

Dechow, Patricia M., and Richard Sloan, 1991, Executive incentives and the horizon problem: an empirical investigation, Journal of Accounting and Economics 14, 51-89.

Dechow, Patricia M., Richard .G. Sloan, and Amy P. Sweeney, 1995, Detecting earnings management, The Accounting Review 2, 193-226.

Dobbie, Will, Paul Goldsmith-Pinkham, and Crystal S. Yang, 2017, Consumer Bankruptcy and Financial Health, The Review of Economics and Statistics 99, 853-869.

Dobbie, Will, and Jae Song, 2015, Debt relief and Debtor Outcomes: Measuring the Effects of Consumer Bankruptcy Protection, The American Economic Review 105, 1272-1311.

Donangelo, Andres, François Gourio, Matthias Kehrig, and Miguel Palacios, 2019, The cross-section of labor leverage and equity returns, Journal of Financial Economics 132, 497 - 518.

Dou, Yiwei, Mozaffar Khan, and Youli Zou, 2016, Labor unemployment insurance and earnings management, Journal of Accounting and Economics 61, 166-184. 
Efendi, Jap, Anup Srivatsava, and Edward P. Swanson, 2007, Why do corporate managers misstate financial statements? The role of option compensation and other factors, Journal of Financial Economics 85, 667-708.

Gao, Huasheng, Huai Zhang, and Jin Zhang, 2018, Employee turnover likelihood and earnings management: evidence from the inevitable disclosure doctrine, Review of Accounting Studies 23, $1424-1470$.

Graham, John R., Campbell R. Harvey, and Shiva Rajgopal, 2005, The economic implications of corporate financial reporting, Journal of Accounting and Economics 2005, 3-73.

Hass, Lars H., Paul Hribar, and Fani Kalogirou, 2019, The Disciplining Effect of Labor Mobility on Managerial Myopia, Working Paper.

Hayn, Carla, 1995, The information content of losses, Journal of Accounting and Economics 20, $125-153$.

Hribar, Paul, and Daniel W. Collins, 2002, Errors in Estimating Accruals: Implications for Empirical Research, Journal of Accounting Research 40, 105-134.

Hribar, Paul, and Nicole Thorne Jenkins, 2004, The Effect of Accounting Restatements on Earnings Revisions and the Estimated Cost of Capital, Review of Accounting Studies 9, 337-356.

İmrohoroğlu, Ayşe, and Şelale Tüzel, 2014, Firm-level Productivity, Risk, and Return, Management Science 60, 2073-2090.

Jensen, Michael C., 2005, Agency Costs of Overvalued Equity, Financial Management 34, 5-19.

Kothari, S.P., Natalie Mizik, and Sugata Roychowdhury, 2016, Managing for the Moment: The Role of Earnings Management via Real Activities versus Accruals in SEO Valuation, The Accounting Review 91, 559-586.

Low, Hamish, Costas Meghir, and Luigi Pistaferri, 2010, Wage Risk and Employment Risk Over the Life Cycle, The American Economic Review 100, 1432-1467.

McNichols, Maureen F., and Stephen R. Stubben, 2008, Does Earnings Management Affect Firms' Investment Decisions?, The Accounting Review 83, 1571-1603. 
Olley, G. Steven, and Ariel Pakes, 1996, The dynamics of productivity in the telecommunications equipment industry, Econometrica 64, 1263-1297.

Oyer, Paul, and Scott Schaefer, 2005, Why do some firms give stock options to all employees?: An empirical examination of alternative theories, Journal of Financial Economics 76, 99-133.

Petroni, Katy Ruby, 1992, Optimistic reporting in the property-casualty insurance industry, Journal of Accounting and Economics 15, 485-508.

Pinto, Roberto, 2019, Levered Employees, Working Paper.

Porter, Michael E., 1992, Capital Choices: The Causes and Cures of Business Myopia (Research Report to the U.S. Government's Council on Competitiveness, Washington D.C.).

Richardson, Thomas, Peter Elliott, and Ron Roberts, 2013, The relationship between personal unsecured debt and mental and physical health: A systematic review and meta-analysis, Clinical Psychology Review 33, 1148-1162.

Roychowdhury, Sugata, 2006, Earnings Management Through Real Activities Manipulation, Journal of Accounting and Economics 42, 335-370.

Thaler, Richard H., Amos Tversky, Daniel Kahneman, and Alan Schwartz, 1997, The Effect of Myopia and Loss Aversion on Risk Taking: An Experimental Test, The Quarterly Journal of Economics 112, 647-661. 


\section{A Variable list and descriptions}

\begin{tabular}{ll}
\hline Variable Label & \multicolumn{1}{c}{ Description } \\
\hline TCR & Panel A: Main Dependent Variables \\
\hline Incidence rate of total injuries and illnesses. An incidence rate of injuries \\
and illness is computed from the following formula: (Number of in- \\
juries and illnesses x 200,000) / Employee hours worked = Incidence \\
rate. The TCR includes all cases recorded on the OSHA Form 300 \\
(Column G + Column H + Column I + Column J). For further infor- \\
mation on injury and illness incidence rates, please visit the Bureau \\
of Labor Statistics' webpage at http://www.bls.gov/iif/osheval.htm. \\
Incidence rate of injuries and illnesses leading to days away from work. \\
An incidence rate of injuries and illness is computed from the following \\
formula: (Number of injuries and illnesses x 200,000) / Employee \\
hours worked = Incidence rate. The DAFWII includes cases recorded \\
in Column H on the OSHA Form 300. For further information on \\
injury and illness incidence rates, please visit the Bureau of Labor \\
Statistics' webpage at http://www.bls.gov/iif/osheval.htm.
\end{tabular}

Sales per Employee

Ratio between firms' total sales and number of employees (Compustat variables sale and $e m p$ ).

Total Productivity

Total factor productivity measured by İmrohoroğlu and Tüzel (2014).

The authors estimate the production function given in

$$
y_{i t}=\beta_{0}+\beta_{k} k_{i t}+\beta_{l} l_{i t}+\omega_{i t}+\epsilon_{i t},
$$

where $y$ is the $\log$ of value added for firm $i$ in year $t ; l$ and $k$ are $\log$ values of labor and capital of the firm, respectively; $\omega$ is the productivity, and $\epsilon$ is the error term. They employ the semiparametric procedure suggested by Olley and Pakes (1996) to estimate the parameters of this production function, and once the production function parameters are estimated, they obtain the firm-level (log) total factor productivity by

$$
\omega_{i t}=y_{i t}-\hat{\beta}_{0}-\hat{\beta}_{l} l_{i t}-\hat{\beta}_{k} k_{i t} .
$$

We label $\omega_{i t}$ as Total Productivity.

Total Earnings

Ratio between earnings before interest and taxes and lagged total assets (Compustat variables ebit and at).

(Continued) 


\begin{tabular}{|c|c|}
\hline Variable Label & Description \\
\hline Total Accruals & $\begin{array}{l}\text { Ratio between total accruals and lagged total assets. Total accruals } \\
\text { (numerator of the ratio) are computed as [(change in current assets - } \\
\text { change in cash and equivalents) - (change in current liabilities - change } \\
\text { in short-term debt) - depreciation]. The Compustat variables used to } \\
\text { construct this measure are at, act, che, lct, } d l c \text {, and } d p \text {. }\end{array}$ \\
\hline Cash Flow & $\begin{array}{l}\text { Cash flow from operations computed as the difference between Total } \\
\text { Earnings and Total Accruals. }\end{array}$ \\
\hline RAM & $\begin{array}{l}\text { Real activities management computed as the sum of abnormal discre- } \\
\text { tionary expenses multiplied by negative one (Abnormal Disx.), abnor- } \\
\text { mal cash flow from operations multiplied by negative one (Abnormal } \\
C F O) \text {, and abnormal production costs (Abnormal Prod.). Abnormal } \\
\text { discretionary expenses, abnormal cash flow from operations, and ab- } \\
\text { normal production costs are computed as per Equations (3), (4), and } \\
\text { (5), respectively, and following Roychowdhury (2006). }\end{array}$ \\
\hline
\end{tabular}

Discretionary Accruals

Modified-Jones

Discretionary accruals measured as per Dechow et al. (1995).

Discretionary Accruals

Dechow-Dichev

Discretionary accruals measured as per Dechow and Dichev (2002).

Restatement

Indicator equal 1 if firms have misstated their financial statements in year $t$ and are sanctioned by ex-post restatements, and 0 otherwise.

Restatement Up Indicator equal 1 if firms have misstated their financial statements upward in year $t$ and are sanctioned by ex-post restatements, and 0 otherwise.

Num. Restatement Number of misstatements that firms have engaged in during year $t$ and sanctioned by ex-post restatements.

Num. Restatement Up Number of upward misstatements that firms have engaged in during year $t$ and sanctioned by ex-post restatements.

Panel B: Key Explanatory Variables

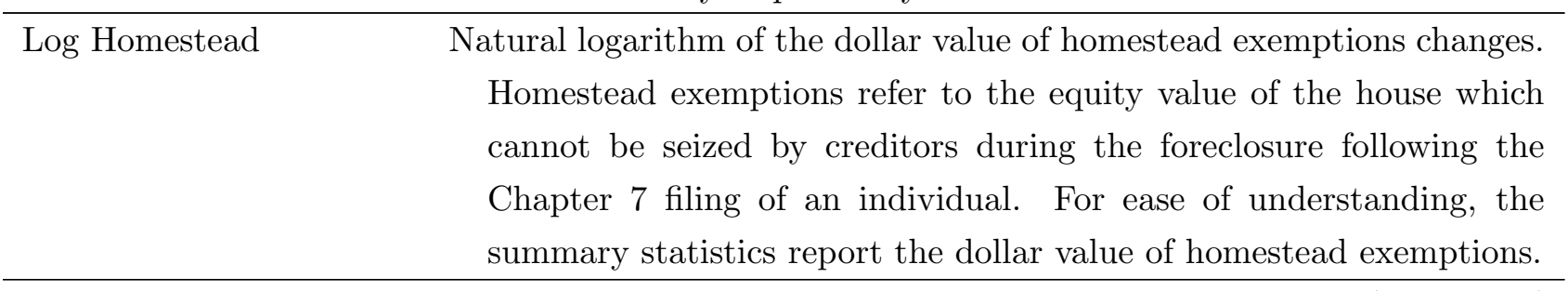

(Continued) 


\begin{tabular}{|c|c|}
\hline Variable Label & Description \\
\hline Log Non-Homestead & $\begin{array}{l}\text { Natural logarithm of the dollar value of non-homestead exemptions } \\
\text { changes. Non-Homestead exemptions refer to the maximum dollar } \\
\text { value of personal items that cannot be seized by creditors during the } \\
\text { liquidation process following the Chapter } 7 \text { filing. This variable refers } \\
\text { to the sum of the protected dollar value of motor vehicles, jewelry, } \\
\text { tools of the trade including implements and books, and the wild card } \\
\text { (special protection that can be applied to any other non-specified per- } \\
\text { sonal items). For ease of understanding, the summary statistics report } \\
\text { the dollar value of non-homestead exemptions. }\end{array}$ \\
\hline
\end{tabular}

\section{Panel C: Firm and State Control Variables}

\begin{tabular}{|c|c|}
\hline Big 4 & $\begin{array}{l}\text { Indicator equal one if firm } i \text { is audited by a Big } 4 \text { audit firm, and zero } \\
\text { otherwise (Compustat variable } a u \text { ). }\end{array}$ \\
\hline Book Leverage & $\begin{array}{l}\text { Book leverage computed as the ratio between the total book value of debt } \\
(\text { Compustat variables } d l t t+d l c) \text { and lagged total assets (Compustat } \\
\text { variable } a t) \text {. }\end{array}$ \\
\hline Dividend & $\begin{array}{l}\text { Ratio between dividends (Compustat variable } d v c \text { ) and lagged total as- } \\
\text { sets (Compustat variable } a t) \text {. }\end{array}$ \\
\hline Market-to-Book & $\begin{array}{l}\text { Ratio between market value of assets (Compustat variables at }+c s h o * \\
\left.\qquad \operatorname{prcc}_{f}-c e q\right) \text { and book value of assets (Compustat variable at). }\end{array}$ \\
\hline $\mathrm{ROA}$ & $\begin{array}{l}\text { Return on assets computed as the ratio between operating income be- } \\
\text { fore depreciation (Compustat variable oibdp) and lagged total assets } \\
\text { (Compustat variable } a t) \text {. }\end{array}$ \\
\hline Size & Natural logarithm of firms' total assets (Compustat variable at). \\
\hline
\end{tabular}

GDP Growth (\%) State-level gross domestic product (GDP) growth rate. Data are from the Bureau of Economic Analysis.

Per-capita Income $(\$) \quad$ State-level per-capita disposable income. It is computed as the total personal income net of personal current taxes.

UI (\$) Unemployment insurance (or unemployment benefits) measured as the natural logarithm of the maximum weekly allowance that an unemployed individual is entitled to receive given his/her state of residency, multiplied by the maximum number of weeks for which an individual in entitled to receive the benefits. For ease of understanding, the summary statistics report the dollar value of unemployment insurance.

Unemployment Rate (\%) State-level unemployment rate. Data are from the US Bureau of Labor Statistics.

Panel D: Additional Variables 


\begin{tabular}{lc}
\hline Variable Label & Description \\
\hline Abnormal Disx. & Abnormal discretionary expenses computed as per Equation (3) follow- \\
Abnormal CFO & ing Roychowdhury (2006), and multiplied by negative one. \\
Abnormal cash flow from operations computed as per Equation (4) fol- & lowing Roychowdhury (2006), and multiplied by negative one. \\
Abnormal Prod. & Abnormal production costs computed as per Equation (5) following Roy- \\
& chowdhury (2006). \\
RAM1 & tionary expenses multiplied by negative one (Abnormal Disx.) and ab- \\
& normal production costs (Abnormal Prod.). Abnormal discretionary \\
& expenses and abnormal production costs are computed as per Equa- \\
& tions (3) and (5), respectively, and following Roychowdhury (2006). \\
Real activities management computed as the sum of abnormal discre- \\
tionary expenses and abnormal cash flow from operations, both mul- \\
tiplied by negative one (Abnormal Disx. and Abnormal CFO, respec- \\
tively). Abnormal discretionary expenses and abnormal cash flow \\
form operations are computed as per Equation (3) and (4), respec- \\
tively, and following Roychowdhury (2006).
\end{tabular}




\section{B Figures}

Figure 1. Homestead exemptions increments

The figure shows the dollar value increments in homestead exemptions in our dataset. More details on the definition of homestead exemptions can be found in Appendix A.

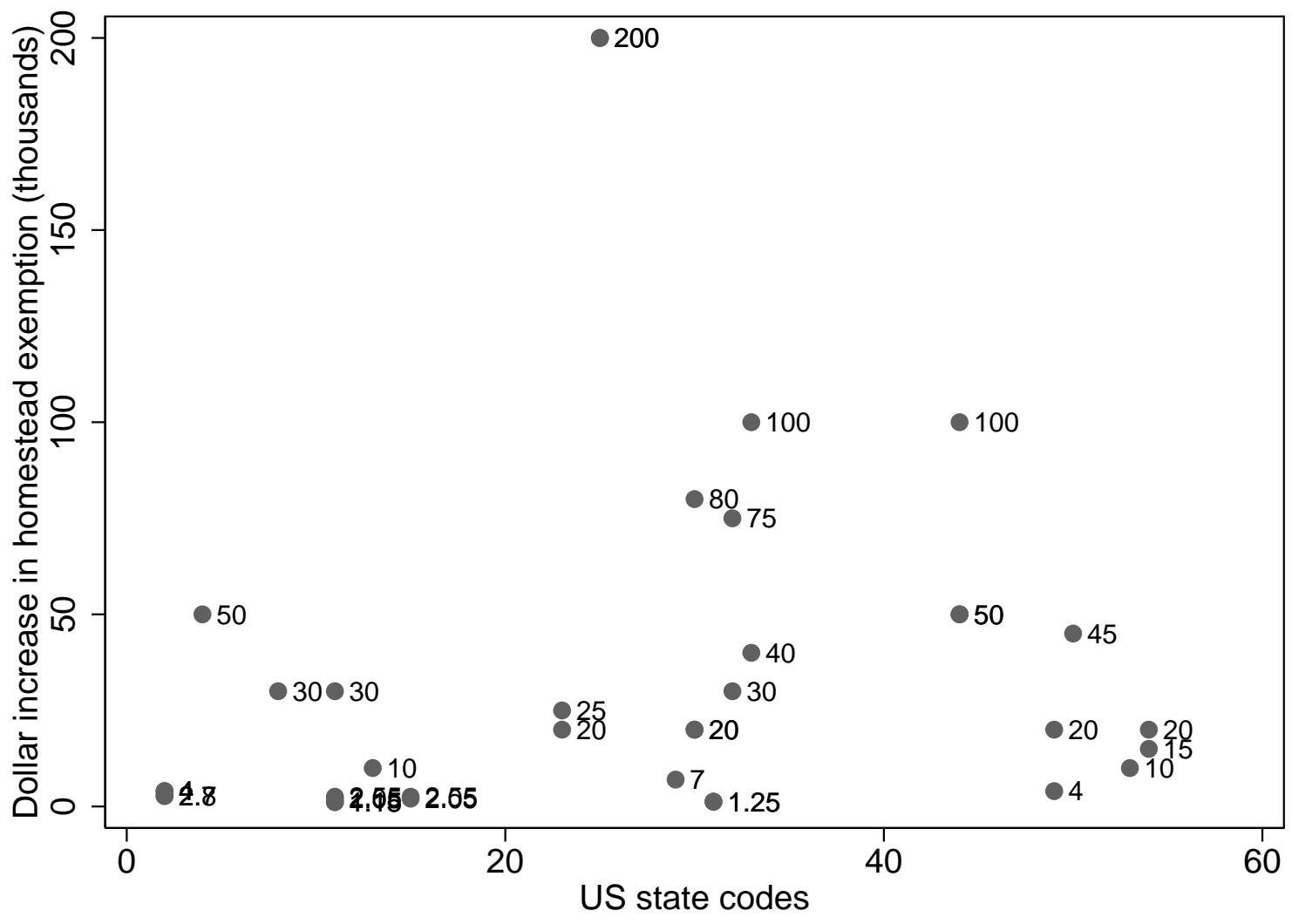


Figure 2. Chapter 7 and Chapter 13 Consumer Bankruptcy Filings

This figure shows the yearly Chapter 7 and Chapter 13 consumer bankruptcy filings. The 2005 is a key year because of the Bankruptcy Abuse Prevention and Consumer Protection Act (BAPCPA) enactment. Data are from Statistics Division of the Administrative Office of the United States Courts.
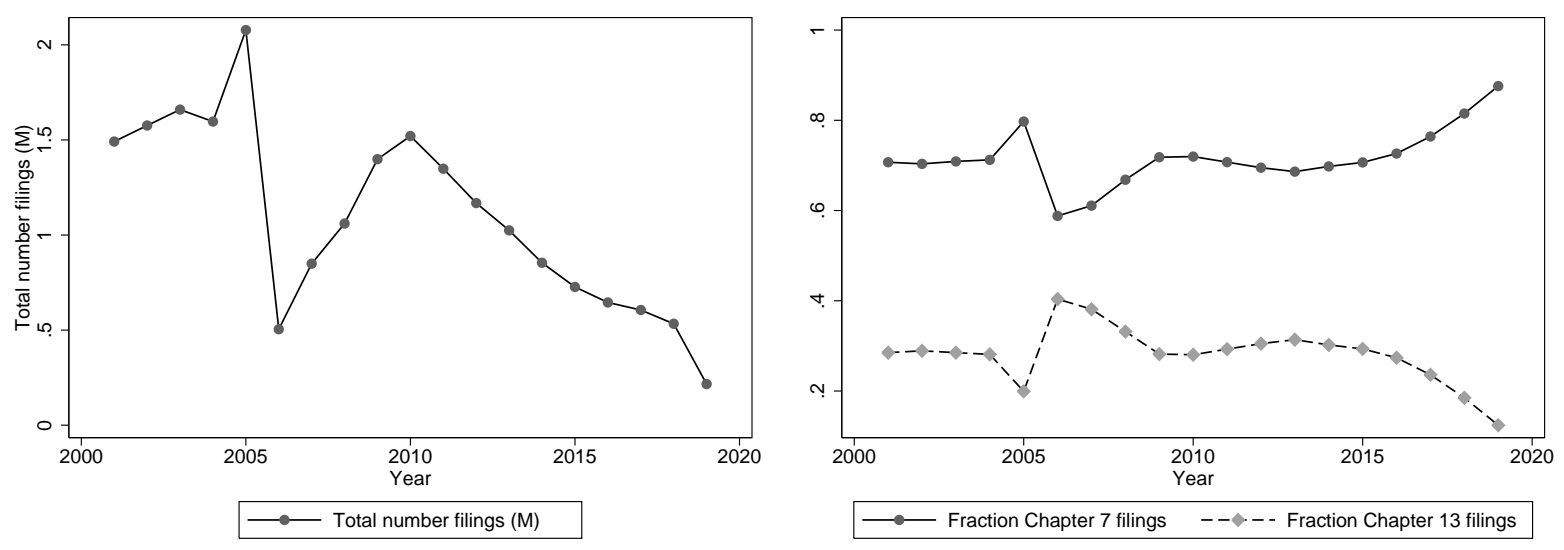
Figure 3. Dynamic effect of homestead exemptions on real activities management

The figure shows the dynamic effect of homestead exemptions on real activities management. Coefficients are the relative effect of homestead exemptions on real activities management with respect to the year in which homestead exemptions increase.

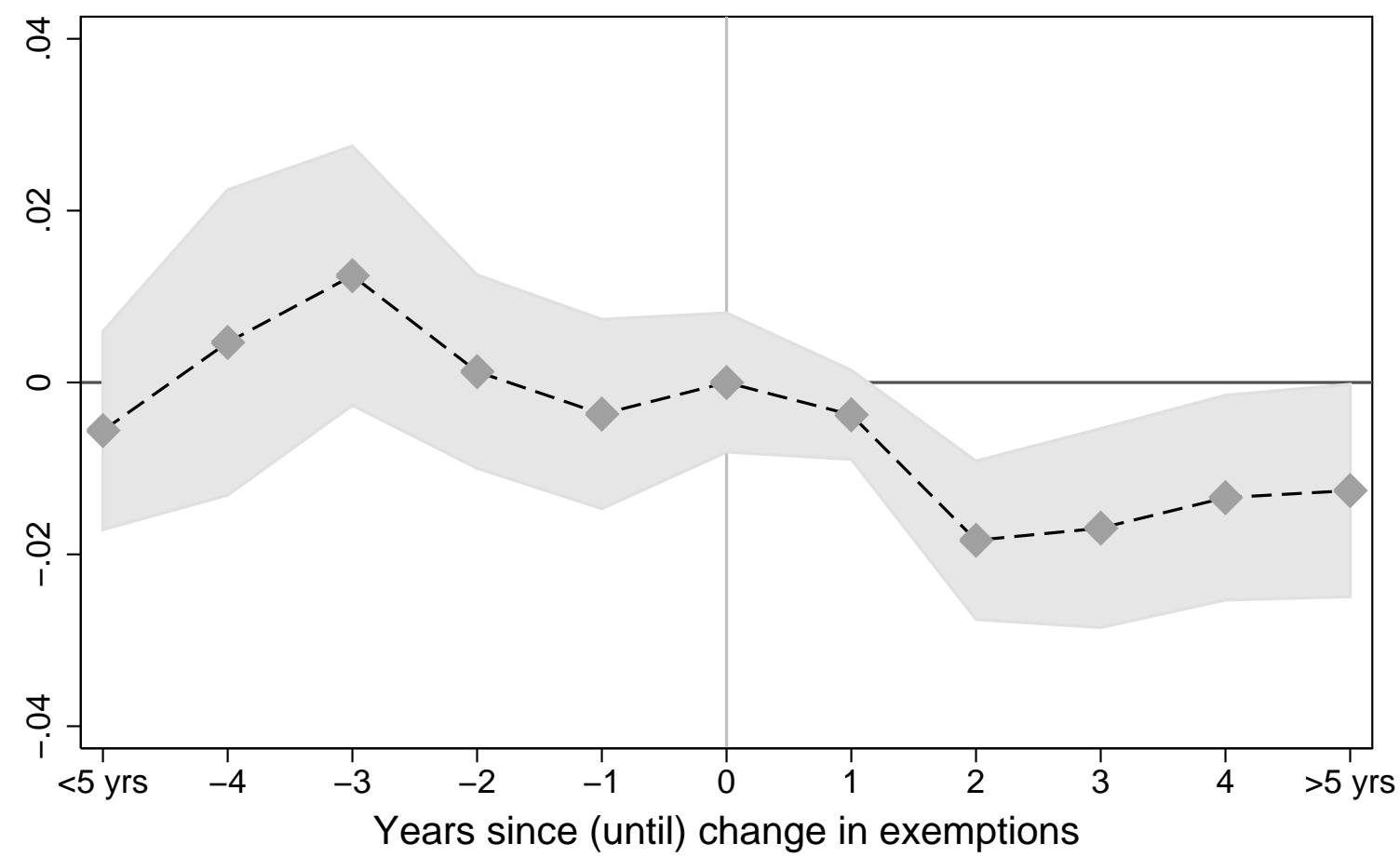

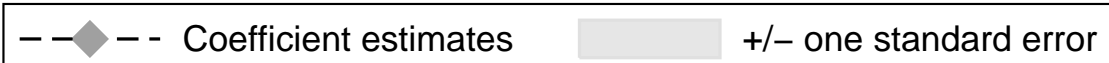


Figure 4. Loss avoidance before and after bankruptcy exemptions increase

The figure shows the empirical distributions of changes in annual net income scaled by total assets as of the beginning of the first year (Net Income I $_{\mathrm{t}}$ Net Income $_{\mathrm{t}-1}$ )/Total Assetst-2 distinguishing between the three years before bankruptcy exemptions increase and the three years after bankruptcy exemptions increase. In both histograms reported at the top of the figure, the distribution interval widths are 0.0050 and the location of zero on the horizontal axis is marked by the vertical line. For example, the first interval to the right of zero contains all scaled changes in earnings in the interval $[0.0000,0.0050)$, the second interval contains $[0.0050,0.0100)$, and so on. The vertical axis labeled frequency represents the number of observations in each earnings change interval. The two graphs at the bottom of the figure report the results of manipulation tests based on the local-polynomial density discontinuity at the zero earnings threshold.

Three years before bankruptcy exemptions increase Histogram
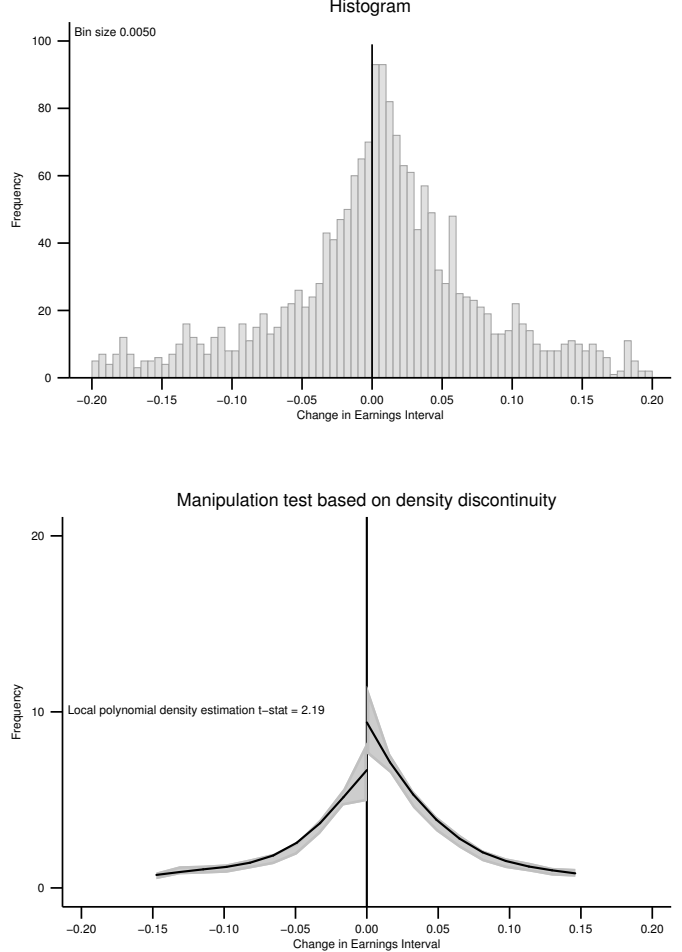

Three years after bankruptcy exemptions increase Histogram
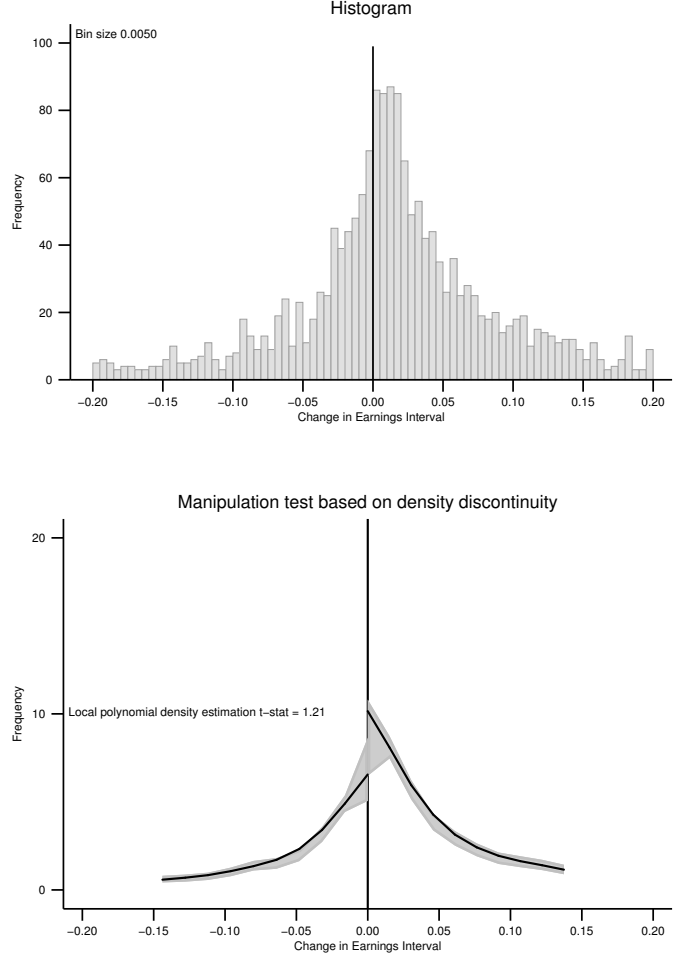


\section{Tables}

\section{Table 1. Summary statistics}

The table reports the summary statistics of the variables used in our main tests. Panel A shows the summary statistics for the main dependent variables. Panel B reports statistics for homestead and non-homestead exemptions, which are the independent test variables capturing the generosity of the consumer bankruptcy system in the United States. Panel C reports statistics for firm-level controls. Panel D shows summary statistics for state-level variables capturing macroeconomic conditions. Lastly, Panel E reports the descriptive statistics of additional variables used for robustness tests. Details on definition, source, and computation of the variables can be found in Appendix A. All financial variables are winsorized at $1 \%$ tails.

\begin{tabular}{|c|c|c|c|c|c|}
\hline & Mean & S.D. & 25 th & Median & 75 th \\
\hline & \multicolumn{5}{|c|}{ Panel A - Main dependent variables } \\
\hline TCR & 10.434 & 2.195 & 8.854 & 10.263 & 11.929 \\
\hline DAFWII & 3.364 & 1.121 & 2.670 & 3.150 & 3.696 \\
\hline Sales per Employee & 5.141 & 0.800 & 4.728 & 5.137 & 5.561 \\
\hline Total Productivity & -0.320 & 0.445 & -0.525 & -0.312 & -0.089 \\
\hline Total Earnings & 0.028 & 0.255 & -0.012 & 0.073 & 0.142 \\
\hline Total Accruals & -0.041 & 0.125 & -0.092 & -0.044 & 0.002 \\
\hline Cash Flow & 0.069 & 0.251 & 0.013 & 0.111 & 0.191 \\
\hline RAM & -0.074 & 0.480 & -0.322 & -0.059 & 0.180 \\
\hline Discretionary Accruals Modified-Jones & -0.045 & 0.158 & -0.114 & -0.034 & 0.032 \\
\hline Discretionary Accruals Dechow-Dichev & -0.002 & 0.094 & -0.032 & 0.005 & 0.040 \\
\hline Restatement & 0.353 & 0.478 & 0.000 & 0.000 & 1.000 \\
\hline Restatement Up & 0.318 & 0.466 & 0.000 & 0.000 & 1.000 \\
\hline Num. Restatement & 0.423 & 0.644 & 0.000 & 0.000 & 1.000 \\
\hline \multirow[t]{2}{*}{ Num. Restatement Up } & 0.371 & 0.597 & 0.000 & 0.000 & 1.000 \\
\hline & \multicolumn{5}{|c|}{ Panel B - Key explanatory variables } \\
\hline Homestead $(\$)$ & 60,704 & 75,526 & 15,000 & 34,850 & 75,000 \\
\hline \multirow[t]{2}{*}{ Non-Homestead (\$) } & 7,661 & 8,610 & 4,250 & 5,706 & 8,500 \\
\hline & \multicolumn{5}{|c|}{ Panel C - Firm-level controls } \\
\hline Big 4 & 0.687 & 0.464 & 0.000 & 1.000 & 1.000 \\
\hline Book Leverage & 0.193 & 0.186 & 0.014 & 0.154 & 0.321 \\
\hline Dividend & 0.007 & 0.017 & 0.000 & 0.000 & 0.003 \\
\hline Market-to-book & 1.952 & 2.378 & 0.824 & 1.244 & 2.149 \\
\hline ROA & 0.078 & 0.177 & 0.039 & 0.114 & 0.174 \\
\hline \multirow[t]{2}{*}{ Size } & 5.120 & 1.923 & 3.759 & 4.966 & 6.333 \\
\hline & \multicolumn{5}{|c|}{ Panel D - State-level controls } \\
\hline GDP Growth (\%) & 5.774 & 2.197 & 4.300 & 5.800 & 7.100 \\
\hline Per-capita Income $(\$)$ & 26,681 & 3,405 & 24,482 & 26,258 & 29,106 \\
\hline UI $(\$)$ & 7,872 & 1,781 & 6,724 & 7,553 & 8,877 \\
\hline \multirow[t]{2}{*}{ Unemployment Rate (\%) } & 5.227 & 1.234 & 4.367 & 5.225 & 6.050 \\
\hline & \multicolumn{5}{|c|}{ Panel E - Additional variables } \\
\hline Abnormal Disx. & -0.052 & 0.271 & -0.171 & -0.016 & 0.091 \\
\hline Abnormal CFO & 0.002 & 0.136 & -0.072 & -0.009 & 0.061 \\
\hline Abnormal Prod. & -0.024 & 0.236 & -0.150 & -0.031 & 0.089 \\
\hline RAM1 & -0.077 & 0.448 & -0.292 & -0.045 & 0.158 \\
\hline RAM2 & -0.050 & 0.276 & -0.185 & -0.030 & 0.098 \\
\hline
\end{tabular}




\section{Table 2. Effect of exemptions on workers' absenteeism and productivity}

The table reports the establishment- and firm-level regression results capturing the effects of debt relief programs on proxies for workers' absenteeism and labor productivity. In particular, the variables capturing workers' absenteeism are Total Case Rate (TCR) and Days Away From Work for Illness-related issues and Injuries $(D A F W I I)$ case rate in columns (1) and (2). Detailed definitions of these variables can be found on the Bureau of Labor Statistics website (https://www.bls.gov/iif/osheval.htm). The dependent variable in column (3) capturing labor productivity is the ratio between firms' sales and the number of their employees (Sales per Employee). The dependent variable in column (4) proxies for total firm productivity (Total Productivity) and is measured as per Imrohoroğlu and Tüzel (2014). The independent variables of interest are Log Homestead and Log Non-Homestead, which measure the natural logarithms of lagged increases in the homestead and non-homestead exemptions, respectively. State-level controls are lagged state GDP Growth, lagged Per-capita Income, and lagged Unemployment Rate. Firm-level controls (in columns (3) and (4)) include the following lagged variables: Big 4, Book Leverage, Dividend, Market-to-Book, ROA, Size, and Total Accruals. All firms' financial controls are winsorized at $1 \%$ tails. Details on the definition, source, and computation of the variables can be found in Appendix A. Standard errors in parentheses are robust and clustered at the state level. $* * *, * *$, and $*$ indicate significance at the $1 \%, 5 \%$, and $10 \%$ level, respectively.

\begin{tabular}{|c|c|c|c|c|}
\hline & \multicolumn{2}{|c|}{ Establishment-level } & \multicolumn{2}{|c|}{ Firm-level } \\
\hline & $(1)$ & $(2)$ & $(3)$ & $(4)$ \\
\hline & TCR & DAWFII & Sales per Employee & Total Productivity \\
\hline \multirow[t]{2}{*}{ Log Homestead $_{t-1}$} & $-0.547^{* *}$ & $-0.222 * *$ & $0.014^{*}$ & $0.016^{* *}$ \\
\hline & $(0.215)$ & $(0.106)$ & $(0.007)$ & $(0.008)$ \\
\hline \multirow[t]{2}{*}{ Log Non-Homestead $t-1$} & 0.351 & 0.036 & 0.012 & $-0.022^{*}$ \\
\hline & $(0.617)$ & $(0.197)$ & $(0.009)$ & $(0.012)$ \\
\hline \multirow[t]{2}{*}{ Intercept } & $-83.280^{* * *}$ & $-20.514^{*}$ & $4.366^{* * *}$ & 0.185 \\
\hline & $(24.115)$ & $(11.366)$ & $(0.312)$ & $(0.578)$ \\
\hline Firm Controls & No & No & Yes & No \\
\hline State Controls & Yes & Yes & Yes & Yes \\
\hline Year FE & Yes & Yes & No & No \\
\hline State FE & Yes & Yes & No & No \\
\hline Industry-by-Year FE & No & No & Yes & Yes \\
\hline Firm FE & No & No & Yes & Yes \\
\hline Adj. R2 & 0.0403 & 0.0387 & 0.8798 & 0.5685 \\
\hline $\mathrm{N}$ & 255,730 & 255,730 & 28,751 & 23,054 \\
\hline
\end{tabular}


Table 3. Effect of exemptions on firm performance

The table reports the multivariate regression results capturing the effects of debt relief programs on proxies for firm performance. In particular, the variables capturing firm performance are earnings before interest and taxes scaled by lagged total assets (Total Earnings) in column (1), Total accruals scaled by lagged total assets (Total Accruals) in column (2), and Cash flow from operations scaled by lagged total assets (Cash Flow) in column (3). By construction, the sum of Total Accruals and Cash Flow equals Total Earnings. The independent variables of interest are Log Homestead and Log Non-Homestead, which measure the natural logarithms of lagged increases in the homestead and non-homestead exemptions, respectively. State-level controls are lagged state GDP Growth, lagged Per-capita Income, and lagged Unemployment Rate. Firm-level controls include the following lagged variables: Big 4, Book Leverage, Dividend, Market-to-Book, and Size. All firms' financial controls are winsorized at $1 \%$ tails. Details on the definition, source, and computation of the variables can be found in Appendix A. Standard errors in parentheses are robust and clustered at the state level. $* * *, * *$, and $*$ indicate significance at the $1 \%, 5 \%$, and $10 \%$ level, respectively.

(1)

$(2)$

(3)

Total Earnings Total Accruals Cash Flow

\begin{tabular}{lccc}
\cline { 2 - 4 } Log Homestead & $0.008^{* *}$ & 0.001 & $0.008^{* *}$ \\
& $(0.004)$ & $(0.002)$ & $(0.004)$ \\
Log Non-Homestead & & -0.004 & $-0.010^{*}$ \\
& $-0.013^{* *}$ & $(0.004)$ & $(0.006)$ \\
Intercept & $(0.006)$ & 0.040 & -0.187 \\
& -0.125 & $(0.112)$ & $(0.180)$ \\
\cline { 2 - 4 } Firm Controls & $(0.158)$ & Yes & Yes \\
State Controls & Yes & Yes & Yes \\
Firm FE & Yes & Yes & Yes \\
Industry-by-Year FE & Yes & Yes & Yes \\
Adj. R2 & Yes & 0.1735 & 0.5807 \\
$\mathrm{~N}$ & 0.6082 & 32,663 & 32,663 \\
\hline
\end{tabular}


Table 4. Effect of exemptions on real activities management

The table reports the coefficients from estimating the model in Equation (2). The dependent variable proxies for firms' real activities management $(R A M)$, and is measured as the sum of abnormal discretionary expenses, abnormal cash flow from operations (both multiplied by negative one), and abnormal production costs. The independent variables of interest are Log Homestead and Log Non-Homestead, which measure the natural logarithms of lagged increases in homestead and non-homestead exemptions, respectively. Firm-level controls include the following lagged variables: Big 4, Book Leverage, Dividend, Market-to-Book, ROA, Size, and Total Accruals. State-level controls include lagged state GDP Growth, lagged unemployment insurance (UI), and lagged Unemployment Rate. We define Transportation (SIC: 40-47), Wholesale (SIC: 50-51), and Retail (SIC: 52-59) as industries that are more likely to have geographically dispersed employees. All firms' financial controls are winsorized at $1 \%$ tails. Details on definition, source, and computation of the variables can be found in Appendix A. Standard errors in parentheses are robust and clustered at the state level. $* * *, * *$, and $*$ indicate significance at the $1 \%, 5 \%$, and $10 \%$ level, respectively.

\begin{tabular}{|c|c|c|c|c|}
\hline & \multicolumn{2}{|c|}{ Full sample } & \multirow{2}{*}{$\begin{array}{c}\begin{array}{c}\text { Less dispersed } \\
\text { employees }\end{array} \\
(3) \\
\text { RAM }\end{array}$} & \multirow{2}{*}{$\begin{array}{c}\text { More dispersed } \\
\text { employees }\end{array}$} \\
\hline & $\begin{array}{c}(1) \\
\text { RAM }\end{array}$ & $\begin{array}{c}(2) \\
\text { RAM }\end{array}$ & & \\
\hline Log Homestead H-1 $_{t}$ & $\begin{array}{c}-0.020^{* * *} \\
(0.007)\end{array}$ & $\begin{array}{c}-0.018^{* * *} \\
(0.006)\end{array}$ & $\begin{array}{c}-0.019^{* *} \\
(0.008)\end{array}$ & $\begin{array}{l}-0.017 \\
(0.027)\end{array}$ \\
\hline Log Non-Homestead ${ }_{t-1}$ & $\begin{array}{c}0.005 \\
(0.010)\end{array}$ & $\begin{array}{c}0.000 \\
(0.007)\end{array}$ & $\begin{array}{l}-0.000 \\
(0.008)\end{array}$ & $\begin{array}{c}0.005 \\
(0.023)\end{array}$ \\
\hline Big 4 & & $\begin{array}{c}-0.023^{* * *} \\
(0.006)\end{array}$ & $\begin{array}{c}-0.022^{* * *} \\
(0.007)\end{array}$ & $\begin{array}{l}-0.029 \\
(0.022)\end{array}$ \\
\hline Book Leverage & & $\begin{array}{c}-0.064^{* * *} \\
(0.023)\end{array}$ & $\begin{array}{c}-0.061^{* *} \\
(0.025)\end{array}$ & $\begin{array}{l}-0.066 \\
(0.061)\end{array}$ \\
\hline Dividend & & $\begin{array}{l}-0.027 \\
(0.170)\end{array}$ & $\begin{array}{c}0.035 \\
(0.161)\end{array}$ & $\begin{array}{l}-0.415 \\
(0.384)\end{array}$ \\
\hline Market-to-book & & $\begin{array}{c}-0.016^{* * *} \\
(0.002)\end{array}$ & $\begin{array}{c}-0.016^{* * *} \\
(0.002)\end{array}$ & $\begin{array}{l}-0.008 \\
(0.015)\end{array}$ \\
\hline ROA & & $\begin{array}{c}-0.211^{* * *} \\
(0.026)\end{array}$ & $\begin{array}{c}-0.214^{* * *} \\
(0.029)\end{array}$ & $\begin{array}{l}-0.181^{*} \\
(0.096)\end{array}$ \\
\hline Size & & $\begin{array}{c}0.043^{* *} \\
(0.018)\end{array}$ & $\begin{array}{c}0.043^{* *} \\
(0.020)\end{array}$ & $\begin{array}{l}0.040^{* *} \\
(0.017)\end{array}$ \\
\hline Total Accruals & & $\begin{array}{l}-0.005 \\
(0.028)\end{array}$ & $\begin{array}{l}0.007 \\
(0.031)\end{array}$ & $\begin{array}{c}-0.093^{* *} \\
(0.037)\end{array}$ \\
\hline Intercept & $\begin{array}{c}0.100 \\
(0.112)\end{array}$ & $\begin{array}{c}0.122 \\
(0.278)\end{array}$ & $\begin{array}{c}0.213 \\
(0.322)\end{array}$ & $\begin{array}{l}-0.448 \\
(0.757)\end{array}$ \\
\hline State Controls & No & Yes & Yes & Yes \\
\hline $\begin{array}{l}\text { Firm FE } \\
\text { Year FE }\end{array}$ & $\begin{array}{l}\text { Yes } \\
\text { Yes }\end{array}$ & $\begin{array}{l}\text { Yes } \\
\text { Yes }\end{array}$ & $\begin{array}{l}\text { Yes } \\
\text { Yes }\end{array}$ & $\begin{array}{l}\text { Yes } \\
\text { Yes }\end{array}$ \\
\hline $\begin{array}{l}\text { Adj. R2 } \\
\mathrm{N}\end{array}$ & $\begin{array}{l}0.7502 \\
30,982\end{array}$ & $\begin{array}{l}0.7567 \\
30,982\end{array}$ & $\begin{array}{l}0.7516 \\
26,049\end{array}$ & $\begin{array}{c}0.7865 \\
4,933\end{array}$ \\
\hline
\end{tabular}


Table 5. Effect of exemptions on accrual-based earnings management

The table shows results from investigating the effects of consumer bankruptcy exemptions on accrual-based earnings management. Results are from estimating the model in Equation (2), with alternative dependent variables. Column (1) dependent variable is discretionary accruals measured as per Dechow et al. (1995), i.e., Discretionary Accruals Modified-Jones. Column (2) dependent variable is discretionary accruals measured as per Dechow and Dichev (2002), i.e., Discretionary Accruals Dechow-Dichev. The independent variables of interest are Log Homestead and Log NonHomestead, which are the natural logarithms of lagged increases in homestead and non-homestead exemptions, respectively. Firm-level controls include the following lagged variables: Big 4, Book Leverage, Dividend, Market-toBook, ROA, Size, and Total Accruals. State-level controls include lagged state GDP Growth, lagged unemployment insurance $(U I)$, and lagged Unemployment Rate. All firms' financial controls are winsorized at $1 \%$ tails. Details on definition, source, and computation of the variables can be found in Appendix A. Standard errors in parentheses are robust and clustered at the state level. $* * *, * *$, and $*$ indicate significance at the $1 \%, 5 \%$, and $10 \%$ level, respectively.

Discretionary Accruals Discretionary Accruals

\begin{tabular}{lcc} 
& Modified-Jones & Dechow-Dichev \\
\cline { 2 - 3 } Log Homestead & 0.001 & 0.004 \\
& $(0.004)$ & $(0.004)$ \\
Log Non-Homestead & & -0.003 \\
& $-0.010^{* *}$ & $(0.002)$ \\
Intercept & $(0.004)$ & -0.078 \\
& -0.080 & $(0.073)$ \\
Firm Controls & $(0.098)$ & Yes \\
State Controls & Yes & Yes \\
Firm FE & Yes & Yes \\
Year FE & Yes & Yes \\
Adj. R2 & Yes & 0.1973 \\
N & 0.2420 & 29,017 \\
\hline
\end{tabular}


Table 6. Effect of exemptions on financial misstatements

The table shows results from investigating the effects of consumer bankruptcy exemptions on firms' misstatement activities. The sample includes only firms that have misstated their financial statements at least once during the sample period (based on the dataset Audit Analytics), and it excludes firms whose misstatements were due to clerical errors. Results are from estimating the model in Equation (2), with the following dependent variables. Column (1) dependent variable is an indicator equal 1 if firms have misstated their financial statements in year $t$ and are sanctioned by an ex-post restatement, and 0 otherwise (Restatement). Column (2) dependent variable is an indicator equal 1 if firms have misstated their financial statements upward in year $t$ and are sanctioned by an ex-post restatement, and 0 otherwise (Restatement $U p$ ). Column (3) dependent variable measures the number of misstatements that firms have engaged in during year $t$ (Num. Restatement). Column (4) dependent variable measures the number of upward misstatements that firms have engaged in during year $t$ (Num. Restatement $U p$ ). The independent variables of interest are Log Homestead and Log Non-Homestead, which measure the natural logarithms of lagged increases in homestead and non-homestead exemptions, respectively. Firm-level controls include the following lagged variables: Big 4, Book Leverage, Dividend, Market-to-Book, ROA, and Size. State-level controls include lagged state GDP Growth, lagged unemployment insurance $(U I)$, and lagged Unemployment Rate. All firms' financial controls are winsorized at $1 \%$ tails. Details on definition, source, and computation of the variables can be found in Appendix A. Standard errors in parentheses are robust and clustered at the state level. $* * *, * *$, and $*$ indicate significance at the $1 \%, 5 \%$, and $10 \%$ level, respectively.

\begin{tabular}{|c|c|c|c|c|}
\hline & $\begin{array}{c}(1) \\
\text { Restatement }\end{array}$ & $\begin{array}{c}(2) \\
\text { Restatement Up }\end{array}$ & $\begin{array}{c}(3) \\
\text { Num. Restatement }\end{array}$ & $\begin{array}{c}(4) \\
\text { Num. Restatement Up }\end{array}$ \\
\hline $\log _{\text {Homestead }}+1$ & $\begin{array}{c}-0.046^{* *} \\
(0.019)\end{array}$ & $\begin{array}{l}-0.044^{*} \\
(0.023)\end{array}$ & $\begin{array}{c}-0.057^{* *} \\
(0.026)\end{array}$ & $\begin{array}{l}-0.051 \\
(0.033)\end{array}$ \\
\hline Log Non-Homestead ${ }_{t-1}$ & $\begin{array}{c}-0.044^{* *} \\
(0.022)\end{array}$ & $\begin{array}{l}-0.042^{*} \\
(0.021)\end{array}$ & $\begin{array}{l}-0.067^{*} \\
(0.034)\end{array}$ & $\begin{array}{l}-0.048 \\
(0.032)\end{array}$ \\
\hline Big 4 & $\begin{array}{l}-0.024 \\
(0.027)\end{array}$ & $\begin{array}{l}-0.021 \\
(0.025)\end{array}$ & $\begin{array}{l}-0.003 \\
(0.036)\end{array}$ & $\begin{array}{c}0.002 \\
(0.033)\end{array}$ \\
\hline Book Leverage & $\begin{array}{c}0.050 \\
(0.053)\end{array}$ & $\begin{array}{c}0.053 \\
(0.050)\end{array}$ & $\begin{array}{c}0.087 \\
(0.070)\end{array}$ & $\begin{array}{c}0.089 \\
(0.058)\end{array}$ \\
\hline Dividend & $\begin{array}{c}0.556 \\
(0.366)\end{array}$ & $\begin{array}{l}0.883^{* *} \\
(0.362)\end{array}$ & $\begin{array}{l}0.985^{* *} \\
(0.488)\end{array}$ & $\begin{array}{l}1.231^{* * *} \\
(0.425)\end{array}$ \\
\hline Market-to-book & $\begin{array}{c}0.006^{* * *} \\
(0.002)\end{array}$ & $\begin{array}{c}0.007^{* * *} \\
(0.002)\end{array}$ & $\begin{array}{c}0.011^{* * *} \\
(0.003)\end{array}$ & $\begin{array}{c}0.011^{* * *} \\
(0.003)\end{array}$ \\
\hline $\mathrm{ROA}$ & $\begin{array}{c}0.179 * * * \\
(0.043)\end{array}$ & $\begin{array}{c}0.183^{* * *} \\
(0.054)\end{array}$ & $\begin{array}{c}0.135^{* *} \\
(0.059)\end{array}$ & $\begin{array}{c}0.137^{* *} \\
(0.068)\end{array}$ \\
\hline Size & $\begin{array}{c}0.047^{* * *} \\
(0.011)\end{array}$ & $\begin{array}{c}0.049^{* * *} \\
(0.012)\end{array}$ & $\begin{array}{c}0.062^{* * *} \\
(0.014)\end{array}$ & $\begin{array}{c}0.058^{* * *} \\
(0.014)\end{array}$ \\
\hline Intercept & $\begin{array}{l}1.257^{*} \\
(0.652)\end{array}$ & $\begin{array}{c}0.920 \\
(0.677)\end{array}$ & $\begin{array}{c}0.785 \\
(0.767)\end{array}$ & $\begin{array}{c}0.376 \\
(0.776)\end{array}$ \\
\hline State Controls & Yes & Yes & Yes & Yes \\
\hline $\begin{array}{l}\text { Firm FE } \\
\text { Industry-by-Year FE }\end{array}$ & $\begin{array}{l}\text { Yes } \\
\text { Yes }\end{array}$ & $\begin{array}{l}\text { Yes } \\
\text { Yes }\end{array}$ & $\begin{array}{l}\text { Yes } \\
\text { Yes }\end{array}$ & $\begin{array}{l}\text { Yes } \\
\text { Yes }\end{array}$ \\
\hline $\begin{array}{l}\text { Adj. R2 } \\
\mathrm{N}\end{array}$ & $\begin{array}{l}0.3397 \\
11,810\end{array}$ & $\begin{array}{l}0.3579 \\
11,810\end{array}$ & $\begin{array}{l}0.3801 \\
11,810\end{array}$ & $\begin{array}{l}0.3862 \\
11,810\end{array}$ \\
\hline
\end{tabular}




\section{Table 7. Cross-sectional tests}

The table shows results from sub-samples analysis according to firms' characteristics. Column (1) and (2) investigate the heterogeneous effects of higher exemptions on firms with different managerial equity incentives, measured as per Coles et al. (2006). Column (3) and (4) report results according to the degree of the labor intensity of firms, measured as per Donangelo et al. (2019). Column (5) and (6) look at the effects of bankruptcy exemptions on firms located in states with different degrees of employees' unionization. The dependent variable across all specifications is $R A M$, and is measured as the sum of abnormal discretionary expenses, abnormal cash flow from operations (both multiplied by negative one), and abnormal production costs. The independent variables of interest are Log Homestead and Log NonHomestead, which measure the natural logarithms of lagged increases in homestead and non-homestead exemptions, respectively. Firm-level controls include the following lagged variables: Big 4, Book Leverage, Dividend, Market-toBook, ROA, Size, and Total Accruals. State-level controls include lagged state GDP Growth, lagged unemployment insurance (UI), and lagged Unemployment Rate. All firms' financial controls are winsorized at $1 \%$ tails. Details on definition, source, and computation of the variables can be found in Appendix A. Standard errors in parentheses are robust and clustered at the state level. $* * *, * *$, and $*$ indicate significance at the $1 \%, 5 \%$, and $10 \%$ level, respectively.

\begin{tabular}{|c|c|c|c|c|c|c|}
\hline & \multicolumn{6}{|c|}{ Dependent Variable RAM } \\
\hline & $(1)$ & (2) & (3) & (4) & $(5)$ & (6) \\
\hline & $\begin{array}{c}\text { High CEO } \\
\text { delta }\end{array}$ & $\begin{array}{c}\text { Low CEO } \\
\text { delta }\end{array}$ & $\begin{array}{c}\text { High labor } \\
\text { intensity }\end{array}$ & $\begin{array}{l}\text { Low labor } \\
\text { intensity }\end{array}$ & $\begin{array}{l}\text { High } \\
\text { union }\end{array}$ & $\begin{array}{l}\text { Low } \\
\text { union }\end{array}$ \\
\hline Log Homestead H-1 $_{t}$ & $\begin{array}{l}-0.003 \\
(0.014)\end{array}$ & $\begin{array}{c}0.013 \\
(0.013)\end{array}$ & $\begin{array}{c}-0.014^{* *} \\
(0.005)\end{array}$ & $\begin{array}{l}-0.010 \\
(0.016)\end{array}$ & $\begin{array}{c}-0.013^{* * *} \\
(0.004)\end{array}$ & $\begin{array}{l}-0.009 \\
(0.010)\end{array}$ \\
\hline Log Non-Homestead ${ }_{t-1}$ & $\begin{array}{c}0.003 \\
(0.013)\end{array}$ & $\begin{array}{c}0.012 \\
(0.015)\end{array}$ & $\begin{array}{c}-0.016^{*} \\
(0.008)\end{array}$ & $\begin{array}{c}0.015 \\
(0.015)\end{array}$ & $\begin{array}{c}0.013 \\
(0.009)\end{array}$ & $\begin{array}{l}-0.008 \\
(0.009)\end{array}$ \\
\hline Intercept & $\begin{array}{c}-0.885^{* *} \\
(0.335) \\
\end{array}$ & $\begin{array}{l}-0.489 \\
(0.356)\end{array}$ & $\begin{array}{c}0.117 \\
(0.269) \\
\end{array}$ & $\begin{array}{l}-0.343 \\
(0.504) \\
\end{array}$ & $\begin{array}{c}0.360 \\
(0.327) \\
\end{array}$ & $\begin{array}{l}-0.208 \\
(0.503)\end{array}$ \\
\hline Firm Controls & Yes & Yes & Yes & Yes & Yes & Yes \\
\hline State Controls & Yes & Yes & Yes & Yes & Yes & Yes \\
\hline Firm FE & Yes & Yes & Yes & Yes & Yes & Yes \\
\hline Year FE & Yes & Yes & Yes & Yes & Yes & Yes \\
\hline Adj. R2 & 0.8499 & 0.8322 & 0.8366 & 0.7487 & 0.7636 & 0.7566 \\
\hline $\mathrm{N}$ & 5,649 & 4,588 & 13,460 & 12,400 & 11,718 & 18,582 \\
\hline
\end{tabular}




\section{Table 8. Alternative measures of real activities management}

The table shows results from investigating the effects of consumer bankruptcy exemptions on alternative proxies for real activities management. Results are from estimating the model in Equation (2), with alternative dependent variables. Column (1) dependent variable is abnormal discretionary expenses multiplied by negative one (Abnormal Disx.). Column (2) dependent variable is abnormal cash flow from operations multiplied by negative one (Abnormal $C F O$ ). Column (3) dependent variable is abnormal production costs (Abnormal Prod.). Column (4) dependent variable is the sum of Abnormal Disx. and Abnormal Prod., whereas Column (5) dependent variabe is the sum of Abnormal Disx. and Abnormal CFO. The independent variables of interest are Log Homestead and Log Non-Homestead, which measure the natural logarithms of lagged increases in homestead and non-homestead exemptions, respectively. Firmlevel controls include the following lagged variables: Big 4, Book Leverage, Dividend, Market-to-Book, ROA, Size, and Total Accruals. State-level controls include lagged state GDP Growth, lagged unemployment insurance (UI), and lagged Unemployment Rate. All firms' financial controls are winsorized at $1 \%$ tails. Details on definition, source, and computation of the variables can be found in Appendix A. Standard errors in parentheses are robust and clustered at the state level. $* * *, * *$, and $*$ indicate significance at the $1 \%, 5 \%$, and $10 \%$ level, respectively.

\begin{tabular}{lccccc}
\hline & $(1)$ & $(2)$ & $(3)$ & $(4)$ & $(5)$ \\
& Abnormal Disx. & Abnormal CFO & Abnormal Prod. & RAM1 & RAM2 \\
\cline { 2 - 6 } Log Homestead $t-1$ & $-0.009^{* *}$ & $-0.004^{* *}$ & $-0.006^{* *}$ & $-0.015^{* *}$ & $-0.012^{* * *}$ \\
& $(0.004)$ & $(0.002)$ & $(0.003)$ & $(0.006)$ & $(0.004)$ \\
Log Non-Homestead $t-1$ & -0.004 & 0.002 & 0.001 & -0.003 & -0.003 \\
& $(0.005)$ & $(0.003)$ & $(0.003)$ & $(0.007)$ & $(0.005)$ \\
Intercept & -0.109 & 0.037 & 0.235 & 0.116 & -0.096 \\
& $(0.100)$ & $(0.072)$ & $(0.152)$ & $(0.224)$ & $(0.142)$ \\
Firm Controls & Yes & Yes & Yes & Yes & Yes \\
State Controls & Yes & Yes & Yes & Yes & Yes \\
Firm FE & Yes & Yes & Yes & Yes & Yes \\
Year FE & Yes & Yes & Yes & Yes & Yes \\
Adj. R2 & 0.7784 & 0.5375 & 0.7190 & 0.7836 & 0.7246 \\
N & 30,982 & 30,982 & 30,982 & 30,982 & 30,982 \\
\hline
\end{tabular}


Table 9. Effect of unemployment insurance and per-capita disposable income

The table shows results from investigating the heterogeneous effects of homestead exemptions increases on states with different levels of unemployment insurance and per-capita disposable income. Results are from estimating the model in Equation (2) with interaction terms on the main explanatory variable. Column (2) interacts changes in Log Homestead with three dummies indicating whether the state is in the top, middle, or bottom tertile of unemployment insurance (i.e., UI). Column (3) interacts shocks in Log Homestead with three dummies indicating whether the state is in the top, middle, or bottom tertile of per-capita disposable income (i.e., Per-capita Income). The dependent variable across all specifications is $R A M$, and is measured as the sum of abnormal discretionary expenses, abnormal cash flow from operations (both multiplied by negative one), and abnormal production costs. Firm-level controls include the following lagged variables: Big 4, Book Leverage, Dividend, Market-to-Book, ROA, Size, and Total Accruals. Statelevel controls include lagged state GDP Growth, lagged unemployment insurance (UI) - not in column (2), and lagged Unemployment Rate. All firms' financial controls are winsorized at $1 \%$ tails. Details on the definition, source, and computation of the variables can be found in Appendix A. Standard errors in parentheses are robust and clustered at the state level. $* * *, * *$, and $*$ indicate significance at the $1 \%, 5 \%$, and $10 \%$ level, respectively.

\begin{tabular}{|c|c|c|c|}
\hline & $\begin{array}{c}(1) \\
\text { RAM }\end{array}$ & $\begin{array}{c}(2) \\
\text { RAM }\end{array}$ & $\begin{array}{c}(3) \\
\text { RAM }\end{array}$ \\
\hline Log Homestead $_{t-1}$ & $\begin{array}{c}-0.018^{* * *} \\
(0.006)\end{array}$ & & \\
\hline x large UI & & $\begin{array}{c}-0.018^{* * *} \\
(0.006)\end{array}$ & \\
\hline $\mathrm{x}$ medium UI & & $\begin{array}{c}-0.019 * * * \\
(0.006)\end{array}$ & \\
\hline x small UI & & $\begin{array}{c}-0.018^{* * *} \\
(0.006)\end{array}$ & \\
\hline x large Per-capita Income & & & $\begin{array}{c}-0.018^{* *} \\
(0.007)\end{array}$ \\
\hline x medium Per-capita Income & & & $\begin{array}{c}-0.018^{* * *} \\
(0.007)\end{array}$ \\
\hline x small Per-capita Income & & & $\begin{array}{c}-0.017^{* *} \\
(0.007)\end{array}$ \\
\hline Log Non-Homestead $t-1$ & $\begin{array}{c}0.000 \\
(0.007)\end{array}$ & $\begin{array}{c}-0.000 \\
(0.007)\end{array}$ & $\begin{array}{c}0.000 \\
(0.007)\end{array}$ \\
\hline Intercept & $\begin{array}{c}0.122 \\
(0.278)\end{array}$ & & \\
\hline Firm Controls & Yes & Yes & Yes \\
\hline State Controls & Yes & Yes & Yes \\
\hline Firm FE & Yes & Yes & Yes \\
\hline Year FE & Yes & Yes & Yes \\
\hline Adj. R2 & 0.7567 & 0.7567 & 0.7567 \\
\hline $\mathrm{N}$ & 30,982 & 30,982 & 30,982 \\
\hline
\end{tabular}

